\title{
Izborni sistem Bosne i Hercegovine: aktuelno stanje i nužne reforme u kontekstu važećih ustavnih rješenja
}

\author{
Zlatan Begić \\ Vanredni profesor \\ Pravnog fakulteta Univerziteta u Tuzli \\ zlatan.begic@gmail.com
}

Sažetak: Izborni sistem Bosne i Hercegovine (dalje: $\mathrm{BiH}$ ) zasniva se na pozitivnim ustavnopravnim rješenjima koja u svom izvornom obliku, kako je poznato, ne omogućavaju konsekventno ostvarenje opšte-prihvaćenih međunarodnih demokratskih standarda u pogledu jednakosti biračkog prava građana. O tome je, u pojedinačnim slučajevima, Evropski sud za ljudska prava u Strazburu već zauzeo stav. Konstantno ignorisanje obaveza u vezi sa usaglašavanjem unutrašnjeg pravnog poretka $\mathrm{BiH}$ sa međunarodnim demokratskim standardima i presudama Evropskog suda za ljudska prava koje predstavljaju obaveze ustavno-pravne naravi dovelo je, ne samo do daljeg kršenja biračkih prava građana po etničkoj osnovi, nego i do daljeg razvoja nedemokratskih političkih koncepata koji teže za uvođenjem novih oblika diskriminacije u fazi izbora. Pri tome se pojmovni instrumentarij tumači i obrazlaže na do sada nepoznat i suštinski pogrešan način u teoriji i praksi ustavnog i javnog prava - poput „legitimnog predstavljanja konstitutivnih naroda”, ,autentičnih predstavnika konstitutivnih naroda”, kao i nastojanja na „nacionalizaciji” konstitutivnih naroda i sl., a u namjeri bilo kakvog teorijskog utemeljenja nekonsekventnih političkih stavova. Pored toga, u uvjetima nedemokratskih ustavnih rješenja i uzimajući u obzir stvarnu moć donošenja odluka unutar institucija, izbornog pobjednika presudno ne određuju građani na izborima, što su pokazali i posljednji opšti izbori 2018. godine nego je, između ostalog, apsolutni izborni pobjednik u smislu formiranja vlasti i mogućnosti blokade implementacije izbornih rezultata promovisan odlukom/Uputstvom Centralne izborne komisije $\mathrm{BiH}$ u pogledu raspodjele delegatskih mjesta u Domu naroda Parlamenta Federacije BiH, te je tako (gotovo unaprijed!) određen nekonsekventnim ustavnim rješenjima i izbornom geometrijom - što dodatno diskvalificira poziciju građanina i opšte-prihvaćene međunarodne demokratske standarde bez kojih demokratsko društvo ne može da postoji i da se razvija. Sve to ozbiljno dovodi u pitanje demokratski legitimitet i kapacitet institucija javne vlasti i princip vladavine prava, te izvršavanje obaveza pravne i političke naravi na putu evropskih integracija. Suprotno tome, pravne obaveze $\mathrm{BiH}$ u pravcu reforme izbornog prava, ma koliko različitih modaliteta mogu da imaju, prilično su jasne i podrazumijevaju, na prvom mjestu, jednakost aktivnog i pasivnog biračkog prava građana bez obzira na etničku pripadnost ili kakvu drugu okolnost, što je i predmet razmatranja ovim povodom.

Ključne riječi: Ustav $\mathrm{BiH}$, konstitutivnost naroda, ravnopravnost građana, demokratski standardi, biračko pravo, reforma 


\section{Uvod}

Ovaj rad sastoji se od četiri međusobno povezane cjeline.

Prvi dio rada posvećen je osnovama teorijske elaboracije vrlo kompleksnih kategorija legaliteta i legitimiteta. Ovi pojmovi u svakodnevnom javnom diskursu u BiH i u dnevno-političke svrhe vulgariziraju se do te mjere da se potpuno izvrće njihova stvarna suština i značaj sa stanovišta opšte-prihvaćenih međunarodnih demokratskih standarda, pogotovo kada je riječ o kategoriji legitimiteta, dok se princip legaliteta potpuno zanemaruje i gura u drugi plan.

Drugi dio rada sadrži razmatranja, na nivou osnovnih principa, o problematici legaliteta i legitimiteta aktuelnog ustavno-pravnog poretka Bosne i Hercegovine, uključujući i uzroke deficita u pogledu legaliteta i demokratskog legitimiteta javne vlasti sa stanovišta opšte-prihvaćenih međunarodnih demokratskih standarda pravne naravi.

U trećem dijelu rada problematizirana su pitanja deficita legaliteta i demokratskog legitimiteta institucija javne vlasti Bosne i Hercegovine.

Četvrti dio rada predstavlja svojevrstan nastavak trećem dijelu, u smislu razmatranja deficita legaliteta i demokratskog legitimiteta unutar izbornog sistema Bosne i Hercegovine. Također je, sa stanovišta demokratskog sadržaja kategorije legitimiteta i opšte-prihvaćenih međunarodnih demokratskih standarda, analiziran politički koncept zasnovan na tezi o tzv. „legitimnom predstavljanju”.

\section{Legalitet i legitimitet: Osnovno pojmovno-teorijsko određenje}

Ukoliko se pođe isključivo od izvornog etimološkog značenja i porijekla, može se zaključiti da su pojmovi legaliteta i legitimiteta veoma slični po svom sadržaju, ili koji se čak preklapaju. Tako, prema Klaiću, riječ legalitet vodi porijeklo od latinske riječi legalitas što znači zakonitost, pravovaljanost, odnosno - utemeljenost u pozitivnim normama pravnog poretka. ${ }^{1}$ Riječi legitimnost i legitiman, prema Klaiću, vode porijeklo od latinske riječi legitimus. ${ }^{2}$ Tako, po svom etimološkom značenju, obzirom na porijeklo riječi, biti legitiman bi značilo biti zakonit, osnovan na zakonu, zakonski, pravedan, pravilan, opravdan, pravovaljan, dok legitimnost znači zakonitost, zakonsko pravo itd.

Dakle, riječ je o dva pojma koja su, u čisto jezičkom smislu, gotovo istoznačni. Međutim, pravna i politička teorija i filozofija odredila je sadržaj ova

\footnotetext{
${ }^{1}$ Bratoljub Klaić, Rječnik stranik riječi, Nakladni zavod Matice Hrvatske, Zagreb, 2004., str. 793.

${ }^{2}$ Ibid., str. 794.
} 
dva pojma na svoj način, a u smislu odnosa između čovjeka pojedinca sa pripadajućim pravima i slobodama, na jednoj strani, i javne vlasti, na drugoj strani, ukupnih odnosa u društvu koji iz toga proizlaze, te civilizacijskih vrijednosti u savremenom kontekstu razvoja. U tom smislu, biti legalan, naprosto znači biti zasnovan na važećem pozitivnom pravu. Međutim, činjenica utemeljenosti na važećem pozitivnom pravu ne mora nužno da znači da subjekt u pitanju posjeduje kvalitet demokratskog legitimiteta.

Primjer za to su brojni totalitarni režimi u prošlosti, koji su bili zasnovani na anticivilizacijskim i antihumanim premisama koje su bile dio pravnih poredaka tih režima, od nacističkog do fašističkog režima i sl. Riječ je, dakle, bilo o režimima koji su posjedovali legalitet, iz prostog razloga što svaka vlast ima moć donošenja ustava, zakona i drugih pravnih akata kojima može da osigura kvalitet legaliteta. Pogotovo ona vlast koja se ostvaruje u uvjetima totalitarnih poredaka koji su, u pravilu, vrlo efikasni u nametanju pravnih normi upravo radi toga što njihovo donošenje nije rezultat širokog konsenzusa građana i političkih subjekata unutar demokratskih procedura koje podrazumijevaju određene faze u donošenju pravnih akata i demokratsku raspravu i usaglašavanje, nego je u rukama pojedinaca i grupa koje imaju moć donošenja pravnih akata - ustava, zakona i sl. na kojima zasnivaju svoje stavove i konkretan način upravljanja na vrlo efikasan način, po vlastitom nahođenju i izvan demokratskih procedura - koje u takvim režimima nisu niti postojale. ${ }^{3}$

Dakle, kategorija legaliteta, sa stanovišta pozitivnog prava, pravnog poretka te u strogo formalnom smislu, je prilično jasna - legalno je ono što je

\footnotetext{
${ }^{3} \mathrm{O}$ totalitarnim, nacističkim i fašističkim režimima vidi: Adolf Hitler, Mein Kampf, http://der-fuehrer.org/Mein\%20Kampf-Serbisch.pdf (datum pristupa: 30. 8. 2020. godine), e-izdanje; Benito Musolini, Đovani Đentile, Doktrina fašizma, http://www.bosanska-desnica.com/Knjige/Benito_Mussolini_-_Doktrina_fasizma.pdf, (datum pristupa 15. 6. 2011. godine), e-izdanje; Ditrih Ekart, Boljševizam od Mojsija do Lenjina, National Socialist World, 1966; Joseph Goebbels, Nazi Sozi: Die Fragen und die Antworten fur die National-Sozialisten, Berlin, 1931, str. 9-10; Marie Harm, Hermann Wiehle, Lebenskunde fur Mittelschulen, Funfer Teil, Klassed 5 fur Madchen, Halle: Hermann Schrodel Verlag, 1942, str. 168-173: Fritz Bennecke, Vom deutschen Volk und seinem Lebensraum, Franz Eher, Munchen, 1937; Jacob Golomb, How to De-Nazify Nietzsche's Philosophical Anthropology? u: Nietzsche, Godfather of Fascism?: On the Uses and Abuses of a Philosophy, priredili: Jacob Golomb, Robert S. Wistrich, Princeton University Press, New Yersey, 2002, str. 19-46; Karl Popper, Otvoreno društvo i njegovi neprijatelji, Tom II, Kruzak, Zagreb, 2003, str. 79; Petar Stričić, Ugušiti sve glasove osim jednoga, Vjesnik, 14. i 15. maj 2005, str. 95; Tim Mason, Intention and Explanation: A Current Controversy about the Interpretation of National Socialism, u Nazism, Fascism and the Working Class, priredila: Jane Caplan, Cambridge University Press, Cambridge, 1995, str. 212-214; Ian Kershaw, Consensus, Coercion and Popular Opinion in the Third Reich: Some Reflections, u: Popular Opinion in Totalitarian Regimes: Fascism, Nazism, Communism, priredio: Paul Corner, Oxford University Press, Oxford-New York, 2009, str. 33-37, Stanley G. Payne, A History of Fascism 1914-1945, Routledge/ Taylor \& Francis e-Library, 2003, str. 80-128; Milan Sufflay, Izabrani politički spisi, Matica Hrvatska, Zagreb, 2000, str. 20-22. itd.
} 
na važećem pravu utemeljeno. To, međutim, nikako ne mora da znači da je i ispravno u civilizacijskom, moralnom, humanističkom, objektivno vrijednosnom - i savremenom demokratskom smislu sve ono što je zapisano u pravnim aktima te što je, kako takvo, obavezujuće. Kategorija legitimiteta, pogotovo u savremenom civilizacijskom i demokratskom smislu predstavlja svojevrsni korektiv sadržaja onoga što je zapisano u pravnim aktima tj. principa legaliteta, odnosno onoga što bi moralo da bude zapisano u pravnim aktima u savremenom civilizacijskom i vrijednosno-demokratskom smislu.

Dakle, dok je kategoriju legaliteta moguće prilično jasno odrediti - kroz ono što je zapisano u pravnim aktima i što se, kao takvo, mora primjenjivati, dotle je pojam legitimiteta u različitim fazama razvoja pravne i političke filozofske misli imao potpuno različit sadržaj i vrijednosna obilježja. Princip legaliteta se u tom smislu pojavljivao kao potpora legitimitetu u pogledu implementacije onoga što se $u$ datom periodu razvoja ljudske civilizacije i u različitim društveno-ekonomskim formacijama smatralo moralnim i vrijednosno ispravnim. Tako se, primjera radi, u robovlasničkim društvima potpuno legitimnim smatrala podjela stanovništva na slobodne građane i robove, pa se svako suprotno ponašanje u smislu izjednačavanja prava jedne i druge kategorije smatralo nelegalnim i strogo je kažnjavano. ${ }^{4}$

U savremenom demokratskom svijetu, dovođenje u robovski položaj bilo kojeg lica - u vrijednosno-moralnom i civilizacijskom smislu je neprihvatljivo, dakle - nelegitimno, a na prvom mjestu nelegalno i strogo kažnjivo mehanizmima pravne države. Dakle, vrijednosno-moralni sadržaj pojma legitimiteta vremenom se mijenjao, različito shvatao i određivao u pojedinim fazama razvoja ljudske civilizacije i u različitim društveno-ekonomskim formacijama s obzirom na historijske okolnosti, različite vrijednosno-moralne sudove i dosegnuti nivo civilizacijskog razvoja.

Sve to je nerazdvojivo bilo povezano sa konceptom suvereniteta u pojedinim fazama razvoja ljudske civilizacije. Po teokratskom konceptu, legitimno, odnosno pravovaljano, pravedno ili opravdano bilo je sve ono što je zasnovano na volji Božijoj - čiji sadržaj su u tu svrhu tumačili vladari koji su prerogative vlasti također vršili po Božijem određenju i volji Božijoj. ${ }^{5}$ Nelegitimno je bilo preispitivati način vladanja ili ličnost vladara po volji Božijoj, jer bi to

\footnotetext{
${ }^{4}$ Vidi o tome: Peter Garnsey, Ideas of Slavery from Aristotle to Augustine, Cambridge University Press, Cambridge-New York-Melbourne, 1999, str. 107-110; Thomas Wiedemann, Greek and Roman Slavery, Routledge/Taylor \& Francis Group, London-New York, 2005, str. 1-2, 33-40. itd.

${ }^{5}$ Monarhijskom obliku vladavine odgovarao je teokratski koncept legitimacije, odnosno opravdanja državne vlasti. Vlast kraljevskih dinastija počivala je upravo na tom konceptu. Pored teokratskog opravdanja, vlast monarha također je počivala na subjektivnom osjećaju vjernosti njegovog plemstva,
} 
značilo preispitivati samog Boga i njegovu volju, pa je to istovremeno bilo i nelegitimno, i nelegalno, te kažnjivo po tada važećim normama. ${ }^{6}$

Pravna i politička filozofija, međutim, vremenom su izgradili sasvim drugačiji pristup sadržaju pojma legitimiteta u čijem ishodištu je čovjek pojedinac sa pravima i slobodama koja mu po rođenju i po samoj prirodi pripadaju. Nakon antičkog perioda, unutar kojeg su i postavljeni principi kasnije oživotvoreni u djelima klasika liberalizma, nakon perioda u kojem se vlast zasnivala na teokratskom konceptu suvereniteta i feudalnim odnosima koji po svojoj suštini negiraju postojanje građanina sa svim njegovim pravima $i$ obavezama, krajem srednjevjekovnog perioda nastupa period potpunijeg teorijskog konceptualiziranja ideja u čijem središtu je čovjek-građanin koji se rađa slobodan, sa pravima koja mu pripadaju činom rođenja i koji je jednak u pravima sa svakim drugim članom zajednice. Tako se, u teorijsko-doktrinarnom smislu, postepeno gradi konstitucija države zasnovane na principima opšte-prihvaćenim i u savremenom svijetu. Prvo na nivou ideja, potom u okviru teorijskog modela, a zatim putem pravnih normi uspostavljaju se demokratski poreci koji počivaju na ovim idejama i principima. Oživotvoruje se koncept države koja je u funkciji građana, te koncept javne vlasti koja je odgovorna građaninu na čijoj volji, u konačnom, i zasniva svoj legitimitet. ${ }^{7}$

na čemu se temeljila i saglasnosti za vladanje. Vidi: Joseph Canning, A History of Medieval Political Tought 300-1450, Routledge/Taylor \& Francis e-Library, 2003, London-New York, str. 47.

${ }^{6} \mathrm{O}$ teokratskom konceptu opravdanja javne vlasti vidi i: Aurelije Augustin, De civitate dei, Kršćanska sadašnjost, Zagreb, 1996; Armand A. Maurer, Medieval Philosophy, Second Edition, Pontifical Institute of Mediaeval Studies, Toronto-Ontario, 1982; Roger Collins, Early Medieval Europe (300-1000), MacMilllan Education, Houndmills-Basingstoke,-Hampshire-London, 1991; David Luscombe, A History of Western Philosophy, Part II: Medieval Thought, Oxford University Press, Oxford-New York, 1997; Frederik Kolpston, Istorija filozofije - Srednjovekovna filozofija, Tom II, BIGZ, Beograd, 1989. itd.

${ }^{7}$ Primjera radi, o Bodenovom (Jean Bodin) konceptu suvereniteta i legitimiteta, te oblicima vladavine vidi: Jean Bodin, Šest knjiga o Republici, Politička kultura, Zagreb, 2002, str. 191-198; Blandine Kriegel, The Rule of the State and Natural Law, u: Natural Law and Civil Sovereignty: Moral Right and State Authority in Early Modern Political Thought, priredili: Ian Hunter, David Saunders, Palgrave Macmillan, Hampshire-New York, 2002, str. 15.; Matthew S.Weinert, Democratic Sovereignty: Authority, Legitimacy, and State in a Globalizing Age, UCL Press/Taylor \& Francis Group, New York, 2007, str. 35-36. itd. O suverenitetu, legitimitetu i odnosima vlasti u kontekstu filozofije Tomasa Hobsa (Thomas Hobbes) vidi: Jeffrey R. Collins, The Allegiance of, Thomas Hobbes, Oxford University Press Inc., New York, 2005, str. 12; S. A. Llojd, Morality in the Philosophy of Thomas Hobbes: Cases in the Law of Nature, Cambridge University Press, New York, str. 134-136; George Wright, Religion, Politics and Thomas Hobbes, Springer, Dordrecht, 2006, str. 213-214; Geoffrey M. Vaughan, Behemoth Teaches Leviathan: Thomas Hobbes on Political Education, Lexington Books, Lanham-Boulder-New York-Oxford, 2002, str. 14-15; Stephen J. Finn, Thomas Hobbes and the Politics of Natural Philosophy, Continuum, London-New York, 2006, str. 55-59. itd.; O Monteskjeovoj (Charles-Louis de Secondat Montesquieu) političkoj filozofiji i odnosima vlasti i vladanja vidi: Balázs Fekete, The Unknown Montesquieu An essay on Montesquieu's intellectual background, Iustum Aequum Salutare, 1/2009, str. 151; Donald S. Lutz, Thinking about Constitutionalism at the Start of the Twenty-First Century (Essays 
S tim u vezi, kategorija legitimiteta, odnosno pravovaljanosti, pravednosti ili opravdanosti doživljavala je svoju evoluciju i rekonstrukciju u vrijednosnom i moralnom smislu - u smislu teorije prirodnog prava i koncepta društvenog ugovora kao preovladavajućih teorijsko-doktrinarnih koncepata prihvaćenih u savremenim demokratskim državama. Pojam legaliteta, kao princip pretežno pravne naravi i formalnog sadržaja po svojoj suštini, i princip legitimiteta pri tome su nerazdvojivo povezani, kao sadržaj i forma, odnosno kao skup vrijednosnih principa koji čine esenciju pojma legitimiteta $\mathrm{u}$ određenom periodu, ali koji bi ostali u domenu teorijskog značaja bez principa legaliteta kojim se osigurava njihova implementacija putem normi pravne države i mehanizama državne prinude.

U savremenom smislu, kada je o legalitetu riječ, potrebno je u razmatranje uzeti principe vladavine prava i ustavne vladavine, bez kojih nema demokratskog društva i države. Ideja konstitucionalizma, koja se ostvaruje putem ustavne vladavine, pri tome je potpora ostvarenju principa vladavine prava

in Memory of Daniel J. Elazar), Publius, Vol. 30, 4/2000, str. 131; Bruce Ackerman, The New Separation of Powers, Harvard Law Review, Vol. 113, 3/2000, str. 645. itd.; O prirodnom stanju, zakonima prirode i izvorima legitimiteta i suvereniteta u kontekstu političke filozofije Džona Loka (John Locke) vidi: Džon Lok, Dve rasprave o vladi, Utopija, Beograd, 2002, str. 237-308; Michael P. Zuckert, Natural Rights and the New Republicanism, Princeton University Press, Priceton-New Jersey, 1994, str. 221-222; Alan P. Grimes, The Pragmatic Course of Liberalism , The Western Political Quarterly, Vol. 9, 3/1956, str. 634; John A. Simmons, Justification and Legitimacy, Ethics, Vol. 109, 4/1999, str. 741742; Paul McLaughlin, Anarchism and Authority: A Philosophical Introduction to Classical Anarchism, Ashgate Publishing Company, Hampshire-Burlington, 2007, str. 178; Allen Buchanan, Political Legitimacy and Democracy, Ethics, Vol. 112, 4/2002, str. 691-692. itd.; O odnosima vlasti i vladanja, suverenitetu i legitimitetu u kontekstu Rusoove (Jean-Jacques Rousseau) političke filozofije vidi: Žan-Žak Ruso, Društveni ugovor, Filip Višnjić, Beograd, 1993; Stephen R. C. Hicks, Explaining Postmodernism: Skepticism and Socialism from Rousseau to Foucault, Scholargy Publishing, Tempe-New BerlinMilwaukee, 2004, str. 91-92; Niko Kolodny, The Explanation of Amour-Propre, Philosophical Review, Vol. 119, 2/2010, str. 167-169; Stefan Grotefeld, Self-Restraint and the Principle of Consent: Some Considerations on the Liberal Conception of Political Legitimacy (Justice in Philosophy and Social Science), Ethical Theory and Moral Practice, Vol. 3, 1/2000, str. 82; Nicholas Dent, Rousseau, Routledge, London-New York, 2005, str. 169-171; Robert Wokler, Rousseau: A Very Short Introduction, Oxford University Press, New York, 2001, str. 72; Jessica Hawkins, Annotated Bibliography on 'Exploring a 'Social Contract' Approach to the Politics of Poverty Reduction', Chronic Poverty Research Centre, Manchester, 2011, str. 27. itd.; O konceptu legitimiteta, suvereniteta i individualističkog pristupa u kontekstu filozofije Džona Stjuarta Mila (John Stuart Mill) vidi: John S. Mill, On Liberty, Yale University Press, New Haven-London, 2003; Daniel Jacobson, Utilitarianism without Consequentialism: The Case of John Stuart Mill, Philosophical Review, Vol. 117, 2/2008, str. 175; Jonathan Riley, Mill on justice, u: Social Justice: From Hume to Walzer, priredili: David Boucher, Paul Kelly, Routledge, Taylor \& Francis e-Library, London-New York, 2005, str. 47-48. itd. Naravno, ovi teoretičari navedeni su samo primjera radi. Pored ovih teoretičara postoji veliki broj drugih koji su dali nemjerljiv doprinos u teorijskom i pravnom razvoju i konceptualiziranju principa koji čine suštinu sadržaja kategorija suvereniteta, legaliteta i legitimiteta u pojedinim fazama razvoja i u savremenom smislu. Tu svakako spadaju i mnogi drugi teoretičari - od antičkih filozofa, pa sve do Džejmsa Mila, Džeremi Bentama, Dejvida Hjuma, Maksa Vebera, Džona Rolsa, Roberta Nozika, Ronalda Dvorkina i mnogih drugih. 
koji ima šire značenje i domašaj. Ustavna vladavina, prosto rečeno, znači dosljedno provođenje volje ustavotvorca zapisane u normama ustavne prirode čime se, ujedno, ostvaruje i potvrđuje princip vladavine prava u svom suštinskom i najvažnijem dijelu. Da bi se ova volja, kao vrhovna pravna zapovijest, adekvatno ostvarila potrebno je donošenje odgovarajućih provedbenih akata - zakona, podzakonskih akata, pojedinačnih pravnih akata itd. kojim se omogućava uvođenje građana u ustavom garantovana prava, osigurava se uživanje ustavom garantovanih sloboda, te funcionisanje strukture demokratske vlasti koja uključuje i mehanizme zaštite ustavnosti i zakonitosti. Tako se ustavnost i zakonitost pojavljuju kao potpora ostvarivanju principa ustavne vladavine i vladavine prava.

U tom smislu, jasno je da koncept vladavine prava ima svoju formalnu i materijalnu stranu. Formalnu stranu koja se odnosi na nužnost postojanja mehanizama i procedura pravne naravi za efikasno provođenje onoga što je normama propisano, prema njihovoj hijerarhiji, te materijalnu stranu koja se odnosi na sadržaj onoga što je u normama zapisano. Tako, autor Lauc pravilno konstatuje da formalna strana vladavine prava ističe njezin proceduralni značaj u kome se vladavina prava pojavljuje kao krucijalna za djelotvornost pravnog poretka ne uzimajući u obzir sadržaj propisa, dok materijalni aspekt vladavine prava predstavlja skup ideala, vrijednosti, ciljeva zasnovanih na javnom moralu, gdje vladavina prava postoji samo ukoliko je sadržaj normi koje se provode ispunjen tim vrijednostima. ${ }^{8}$

Dakle, dok je legalitet kao princip i mehanizam provođenja prava pretežno po svojoj svrsi ostao isti, pojam legitimiteta u cijelosti je, teorijski i pravno, rekonstruisan u odnosu na objektivni vrijednosni, ciljni, moralni i svaki drugi sadržaj u kontekstu civilizacijskog razvoja čovječanstva i prodora humanističkih ideja u posljednjih nekoliko stoljeća. U savremenom smislu, još od buržoaskih revolucija, pa sve do danas, ne može se uopšte govoriti o legitimitetu izvan demokratskog legitimiteta. Ustvari, savremeni demokratski legitimitet, između ostalog, predstavlja i materijalnu stranu vladavine prava - kako to Lauc označava, odnosno skup ideala, vrijednosti i ciljeva koji polaze od nespornih demokratskih vrijednosti - jednakopravnosti, zabrane diskriminacije po bilo kojem osnovu, garancija i poštivanja ljudskih prava i sloboda, demokratske javne vlasti i sl. Bilo kakav skup vrijednosnih sudova, ideja, ciljeva ili stavova koji mogu činiti sadržaj konkretnih politika, a koji ne uvažavaju demokratske vrijednosti, koje su u međuvremenu dobile

${ }^{8}$ Vidi o tome: Zvonimir Lauc, Načelo vladavine prava u teoriji i praksi, Pravni vjesnik, 2016, 3-4/32, str. 51. 
karakter opšte-prihvaćenih međunarodnih standarda pravne naravi, ne može se smatrati legitimnim u bilo kojem smislu na aktuelnom nivou razvoja ljudske civilizacije.

U savremenom demokratskom kontekstu, pojam legitimiteta može se posmatrati u širem i užem smislu. Širi pristup pojmu legitimiteta može se označiti kao materijalno-subjektivni, a uži kao formalno-objektivni pristup. U širem smislu legitimitet podrazumijeva stanje pri kojem se građani pridržavaju zakona donesenih od strane vlasti iz uvjerenja da ti zakoni, kao i vlast koja ih donosi, slijede najviše interese građana i države kao cjeline. Ovdje je, dakle, riječ o potpuno subjektivnom odnosu onih nad kojima se vlada. Objektiviziranje kvaliteta demokratskog legitimiteta u materijalnom smislu i u demokratskim državama vrši se putem vladavine prava, odnosno principa ustavnosti i zakonitosti odluka javne vlasti putem kojih se vrše prerogativi vlasti. Ako su odluke javne vlasti u skladu sa ustavom i zakonom u demokratskom poretku, onda, sa stanovišta tih odluka, odnosno načina na koji se vlada - javna vlast posjeduje demokratski kapacitet i legitimitet. Ona, pod takvim okolnostima, ujedno posjeduje i kvalitet legaliteta. Takvo stanje prisutno je u zemljama sa demokratskim ustavima. Ono što nužno prethodi materijalnom legitimitetu u demokratskoj državi je objektivno-formalni legitimitet institucija javne vlasti, koji se stiče u proceduri demokratskih izbora, a potom poštivanjem demokratskih procedura pri donošenju odluka/zakona od strane demokratski izabrane vlasti. A ono što prethodi bilo kakvoj vrsti legitimiteta u demokratskoj državi, kao nužna pretpostavka ostvarivanja demokratskog legitimiteta, jeste legalitet odnosno na ustavu i zakonima zasnovan formalni i materijalni demokratski legitimitet javne vlasti.

U savremenim demokratskim državama, vlast je legalna i legitimna ukoliko je izabrana na demokratski način, uz uvažavanje načela opšteg i jednakog aktivnog i pasivnog biračkog prava građana i ostalih demokratskih načela i procedura izbora. Odluke tako izabrane vlasti legalne su, time i legitimne, ukoliko su donesene po propisanim procedurama. Dakle, legitimitet odluka demokratski izabrane vlasti se podrazumijeva sa formalno-procesnog stanovišta.

U stvari, ovdje je riječ oborivoj pretpostavci, jer se pitanje legitimiteta odluka bilo koje vlasti, tako i one koja je demokratski izabrana, može problematizirati sa stanovišta njihovog sadržaja, odnosno sa stanovišta činjenice da li - i u kojoj mjeri slijede princip vladavine prava i ustavne vladavine. Dakle, u savremenim demokratskim državama, materijalni legitimitet javne vlasti je objektiviziran kroz principe vladavine prava, ustavne vladavine, ustavnosti i zakonitosti, te osiguran mehanizmima njihove zaštite. Međutim, materijalni 
legitimitet javne vlasti sa stanovišta odluka/zakona kojima se vlada, u određenim graničnim situacijama, može da bude narušen čak i pod uslovom da se data odluka/zakon nalazi unutar granica koje postavlja ustavni akt demokratske države ukoliko unutar tog prostora, u potrebnoj mjeri, ne slijedi opšti interes društva, odnosno ne uvažava individualne interese većine članova zajednice - sa stanovišta njihovog subjektivnog uvjerenja o svrsishodnosti takvih akata.

U prošlosti su postojali totalitarni režimi koji svoju vladavinu nisu zasnivali na formalnom legitimitetu koji se stiče na demokratskim izborima, nego na legalitetu totalitarne države, odnosno materijalnom legitimitetu koji je slijedio anticivilizacijske $\mathrm{i}$ antihumane ciljeve objedinjene u pravnim normama za koje je postojalo subjektivno uvjerenje većine o njihovoj ispravnosti i prihvatljivosti. Pri tome se može govoriti o legitimnosti zakona sa stanovišta njihovog sadržaja i, s tim u vezi, subjektivnog uvjerenja građana da su po svom sadržaju, odnosno po vrijednostima koje štite i/ili uspostavljaju - ti zakoni legitimni, sa jedne strane, te sa stanovišta organa i procedura po kojima se zakoni donose.

Interesantno je da su sve totalitarističke ideologije polazile od šireg materijalnog-subjektivnog pristupa pojmu legitimiteta. Proceduralno-formalna strana legitimacije javne vlasti, na prvom mjestu u smislu načina njenog izbora pa onda i u pogledu procedura donošenja odluka, bivala je potisnuta u drugi plan. Tako se pod legitimnom vlašću, pojednostavljeno rečeno, u nacističkoj Njemačkoj smatrala ona vlast koja osigurava napredak germanske rase, a u fašizmu to je ona vlast koja državi podređuje sve njene građane i njihova prava i slobode. Prema ovim doktrinama vlast je legitimna dok donosi odluke koje po svom sadržaju omogućavaju provođenje navedenih ciljeva, bez obzira na način donošenja odluka i bez obzira na način izbora donosioca takvih odluka, i to sve dotle dok većina građana posjeduje subjektivno uvjerenje o ispravnosti takvih odluka. Takvo uvjerenje obično se kreiralo mitomanijom, snažnim pritiskom na javnost, ali i represivnim metodama totalitarnog državnog aparata koji nije tolerisao bilo kakvu kritiku ili stavove suprotne vladajućoj ideologiji. Pri tome, ove ideologije nisu poznavale nikakve garancije objektivno-procesnog karaktera sa kojima bi se osiguralo objektiviziranje i kvantificiranje takvih uvjerenja subjektivnog karaktera. Dakle, u ovakvim sistemima vlast legitimiše sama sebe kroz donošenje odluka sa odgovarajućim materijalnim sadržajem. Izborna legitimacija potisnuta je u drugi plan, odnosno, takva vrsta legitimacije niti je bila potrebna niti je, sa stanovišta režima na vlasti, bila poželjna. 
Prema savremenoj demokratskoj doktrini, međutim, pojam legaliteta i pojam legitimiteta moraju se međusobno podudarati. To znači da najviši demokratski standardi i mehanizmi moraju biti utemeljeni u pozitivnim normama pravnog poretka, odnosno moraju biti sastavni dio pravnog sistema, kako bi legalna vlast istovremeno bila i legitimna u demokratskom smislu. Odatle proizilazi i kvalitet formalno-objektivnog legitimiteta koji se stiče u proceduri demokratskih izbora zasnovanih na opšte-prihvaćenim međunarodnim demokratskim standardima pravne naravi, na prvom mjestu. Samo takva - legalna i legitimna vlast u smislu demokratskog načina njenog izbora može da donosi legitimne i legalne odluke sa stanovišta njihovog sadržaja. Ukoliko, međutim, pravni poredak sadrži norme koje su suprotne opšte-prihvaćenim međunarodnim demokratskim standardima pravne naravi, tj. norme kojima se uspostavlja diskriminacija na bilo kojem osnovu u fazi izborne legitimacije javne vlasti ili se na drugi način krše opšte-prihvaćeni međunarodni demokratski standardi, onda tako izabrana vlast ne može da ima kvalitet demokratskog legitimiteta u formalno-objektivnom smislu.

Namjera ovog dijela rada nije u teorijskoj elaboraciji pojmova legaliteta i legitimiteta u različitim društveno-ekonomskim formacijama i u različitim fazama razvoja ljudske civilizacije u cjelini, što nadilazi svrhu i kapacitete ovog rada. Namjera je ukazati da je riječ o vrlo složenim kategorijama, koje se u Bosni i Hercegovini često puta nedopustivo pojednostavljuju i vulgariziraju, naročito pojam legitimiteta koji je izvrgnut svojoj suprotnosti za potrebe nacionalističkih politika i daljih podjela unutar zemlje. Pri tome se potpuno zanemaruje kvalitet legaliteta koji prethodi kategoriji legitimiteta u demokratskom društvu, kao i uzročno-posljedična veza između legaliteta i legitimiteta u demokratskom društvu, o čemu će više biti riječi u tekstu koji slijedi.

\section{Legalitet i legitimitet aktuelnog ustavnog poretka Bosne i Hercegovine i uzroci deficita legaliteta i demokratskog legitimiteta javne vlasti}

Sasvim je jasno da su Dejtonskim i Vašingtonskim mirovnim sporazumima napravljeni brojni neprincipijelni kompromisi koji su se odrazili i na kvalitet legaliteta i deficit demokratskog legitimiteta aktuelnog ustavnog poretka i institucija javne vlasti. Pod patronatom međunarodne zajednice nametnuti su ustavni akti kojima je izvršena unutrašnja reorganizacija ustavnog uređenja zemlje, pri čemu se više vodilo računa o real-političkom stanju nego o 
pravnim i demokratskim aspektima tranzicije sa jednog na drugi model unutrašnje organizacije. ${ }^{9}$

U uvjetima demokratskog ustavno-pravnog poretka, kakav je bio poredak Republike $\mathrm{BiH}$, ustavni kontinuitet je preduvjet legaliteta i legitimiteta novouspostavljenog unutrašnjeg ustavnog uređenja. Prosto rečeno, to je stanje pri kojem se - sa stanovišta legaliteta i demokratskog legitimiteta ustavni poredak dejtonske BiH u cijelosti morao zasnivati na odredbama ranijeg ustavnog akta. To je u formalno-proceduralnom smislu samo djelimično osigurano na vrlo "nategnut" i prilično diskutabilan način, što ukazuje na neprincipijelan stav kreatora mirovnih rješenja prema $\mathrm{BiH}$, ali i prema nespornim vrijednostima unutar demokratskog društva - kakve su vladavina prava, legalitet i legitimitet ustavnog poretka koji je, u slučaju Republike BiH, bio izložen otvorenoj agresiji i izvanpravnom djelovanju.

Tako je, u namjeri da se osigura princip legaliteta, nakon potpisivanja Vašingtonskog mirovnog sporazuma, Skupština Republike BiH izabrana na posljednjim demokratskim izborima 1990. godine, u čijem radu nisu učestvovali poslanici SDS-a i još nekih manjih srpskih etničkih partija, izglasala Ustavni zakon. Tim Zakonom konstituisana je Ustavotvorna skupština Federacije $\mathrm{BiH}$, te su dopunjene odredbe Ustava Republike $\mathrm{BiH}$ sa čime je formalno-pravno omogućeno provođenje Vašingtonskog mirovnog sporazumom. ${ }^{10}$

Ustavotvorna skupština, uspostavljena na naprijed navedeni način, donijela je Ustav Federacije BiH. Ne treba posebno podsjećati da je ovaj ustavni akt prethodno dogovoren i potpisan kao dio Vašingtonskog mirovnog sporazuma. Na ovaj način uspostavljena je Federacija BiH kao svojevrsni subjekt javnog prava sa nejasnim i nedefinisanim statusom unutar još uvijek postojećeg ustavnog poretka Republike $\mathrm{BiH}$, ali sa utvrđenom strukturom institucija i nadležnosti. Na taj način učinjen je prvi korak u redefinisanju unutrašnjeg ustavnog poretka Republike $\mathrm{BiH}$. U formalnom smislu ovim se nastojala uspostaviti unutrašnja pravna veza između unutrašnjeg ustavnog uređenja Republike $\mathrm{BiH}$, čime bi se osigurao ustavno-pravni kontinuitet, time

\footnotetext{
${ }^{9} \mathrm{O}$ opštem okvirnom sporazumu za mir u BiH i Vašingtonskom sporazumu vidi šire: Kasim Trnka, Ustavno pravo, Fakultet za javnu upravu Sarajevo, 2006., str. 103-106; Derek Chollet, The Road to the Dayton Accords: A Study of American Statecraft, Palgrave Macmillan, 2005, str. 133-181; Florian Bieber, Post-war Bosnia: Ethnicity, Inequality and Public Sector Governance, Palgrave Macmillan, 2006. str. 40-86; David Chandler, Bosnia: Faking Democracy After Dayton, Pluto Press, 2000, str. 66-89; Omer Ibrahimagić, Državno uređenje Bosne i Hercegovine, Autor, 2005, str. 79-84; Carrie Manning, The Making of Democrats, Palgrave Macmillan, 2008, str. 73-85. itd.

${ }^{10}$ Vidi o tome: Kasim Trnka, op. cit., str. 100-101.
} 
i kakav-takav legalitet donesenih odluka u pogledu konstituisanja federalne Ustavotvorne skupštine i Ustava Federacije BiH kojeg je donijelo ovo tijelo.

Ustav Bosne i Hercegovine također je dio međunarodnog sporazuma, ali ovaj ustavni akt, za razliku od Ustava Federacije BiH, nikada nije usvojen unutar nadležnog predstavničkog tijela i po utvrđenoj proceduri. Uprkos tome, između pravnog poretka Republike $\mathrm{BiH}$ i pravnog poretka uspostavljenog dejtonskim Ustavom postoji indirektna pravna veza budući da je Vašingtonskim sporazumom ostavljena mogućnost dogradnje ustavnog sistema u pravcu njegove dalje unutrašnje transformacije. Tako je ovim sporazumom utvrđeno: „Odluke o ustavnom ustrojstvu područja Republike Bosne i Hercegovine s većinskim srpskim pučanstvom donijet će se tijekom pregovora o mirnom rješenju i na Međunarodnoj konferenciji o bivšoj Jugoslaviji."11

Sa stanovišta međunarodnog prava, ovakva vrsta intervencije u unutrašnji pravni poredak jedne međunarodno priznate zemlje sa demokratskim ustavnim poretkom kakav je bio poredak Republike $\mathrm{BiH}$, te pod okolnostima otvorene agresije i totalnog rata, mogla se opravdati, odnosno legitimisati potrebom uspostavljanja i održavanja međunarodnog mira i sigurnosti kao legitimnog cilja i vrijednosti najvišeg ranga po međunarodnom pravu. Međutim, i pored navedenog, a imajući u vidu sve okolnosti, ipak u teoriji i praksi postoje brojna sporenja o legalnosti, time i legitimnosti, u formalnom i materijalnom smislu tako donesenih akata sa stanovišta unutrašnjeg ustavnog poretka Republike BiH kao međunarodno priznate države. Kako god, Vašingtonskim i Dejtonskim mirovnim sporazumom provedena je unutrašnja transformacija ustavnog uređenja i poretka $\mathrm{BiH}$, ali su ostale dileme u pogledu legalnosti i legitimnosti takvog zahvata u njen pravni poredak, kako sa stanovišta unutrašnjeg poretka Republike BiH koji je bio jedini legalan poredak prije i tokom agresije - tako i sa stanovišta međunarodnog prava.

Međutim, pretenciozno bi bilo tvrditi da aktuelni ustavno-pravni poredak posjeduje kvalitet punog legaliteta i demokratskog legitimiteta zasnovano na ustavnom kontinuitetu sa prethodnim poretkom demokratske države - Republike BiH. Sa stanovišta načina njegovog donošenja, Ustav BiH spada u kategoriju nametnutih ustava. Pri tome, takva vrsta pristupa, odnosno evidentnog ignorisanja vladavine prava, odnosno principa legaliteta i demokratskog legitimiteta pri uspostavljanju novog oblika unutrašnjeg ustavnog uređenja i uvažavanja real-politika velikodržavne naravi suprotnih i unutrašnjem i međunarodnom pravu, rezultirala je nekonsekventnim ustavnim rješenjima

\footnotetext{
${ }^{11}$ Vidi: Miroslav Tuđman; Ivan Bilić, Planovi, sporazumi, izjave o ustavnom ustrojstvu Bosne i Hercegovine 1991-1995. Zagreb, 2005, str. 375.
} 
koja dalje dovode u pitanje legitimitet i legalitet tako uspostavljenog sistema institucija javne vlasti i čitavog ustavnog poretka, o čemu će više biti riječi u tekstu koji slijedi.

\section{Problem deficita legaliteta i demokratskog legitimiteta javne vlasti u Bosni i Hercegovini}

Iako je Opštim okvirnim sporazumom za mir u BiH uspostavljen diskriminatorski sistem izbora organa javne vlasti, što je potvrđeno i presudama Evropskog suda za ljudska prava, ipak Ustav BiH sadrži norme koje predstavljaju jasan pravni osnov za usaglašavanje unutrašnjeg ustavnog poretka $\mathrm{BiH}$ i izbornog sistema sa opšte-prihvaćenim međunarodnim demokratskim standardima pravne naravi. Riječ je o odredbama pravne naravi, pa prema tome i obavezama koje predstavljaju obaveze pravne naravi, koje se nikako ne bi smjele ignorisati sa stanovišta vladavine prava i implementacije Opšteg okvirnog sporazuma za mir u BiH.

Naime, dugogodišnje neprovođenje i ignorisanje presuda Evropskog suda za ljudska prava u Strazburu, zapravo, predstavlja blokadu u procesu implementacije ovog mirovnog sporazuma. Tako, pored toga što Ustav $\mathrm{BiH}-\mathrm{kao}$ dio tzv. Dejtonskog mirovnog sporazuma upućuje na neposrednu primjenu Evropske konvencije za zaštitu ljudskih prava i temeljnih sloboda i njenih Protokola, član III/3.b) Ustava BiH referira se na primjenu opštih načela međunarodnog prava koja su, u skladu sa navedenim članom, sastavni dio pravnog poretka države $\mathrm{BiH}$ i entiteta. Jedno od tih načela je i načelo pacta sunt servanda, koje podrazumijeva izvršavanje međunarodno preuzetih obaveza $\mathrm{u}$ dobroj vjeri. Ova odredba Ustava $\mathrm{BiH}$ od naročitog je značaja u situaciji pri kojoj je BiH ratifikovala Evropsku konvenciju, uključujući i njene Protokole. Činom njene ratifikacije aktivirana je odredba člana III/3.b) Ustava BiH koja, upućujući na obaveznost primjene opštih načela međunarodnog prava među kojima je i načelo pacta sunt servanda, zapravo upućuje na obaveznost usklađivanja cjelokupnog pravnog poretka uključujući i Ustav BiH sa obavezama pravne naravi koje proizilaze iz ratifikovanih međunarodnih sporazuma. Čin ratifikacije bilo kojeg međunarodnog sporazuma po sili navedene ustavne odredbe, te po osnovu principa lex posterior derogat legi priori, nameće nesumnjivu obavezu pravne naravi na usklađivanje unutrašnjeg pravnog poretka sa obavezama iz ovim sporazuma, te svako neizvršavanje ovih obaveza predstavlja ne samo kršenje međunarodnog ugovornog prava, nego i Ustava $\mathrm{BiH}$ sa stanovišta navedene, ali i drugih ustavnih odredbi među kojima je i 
odredba člana I/2. koja također upućuje na demokratska načela, te koja propisuje da je $\mathrm{BiH}$ demokratska država koja funkcioniše u skladu sa zakonom i na osnovu slobodnih i demokratskih izbora. ${ }^{12}$

Pored toga, Evropska konvencija i njeni Protokoli, uključujući i brojne druge međunarodne instrumente za zaštitu ljudskih prava i sloboda kojima se insistira na međunarodnim demokratskim standardima u vezi sa jednakošću i zabranom diskriminacije u oblasti izbornih prava građana, na snazi su i neposredno se primjenjuju i po sili samog Ustava BiH. Međutim, dugogodišnja praksa tumačenja i primjene Ustava BiH odredila je položaj Evropske konvencije i njenih Protokola, te drugih međunarodnih instrumenata na koje se Ustav BiH referira na način da ovi instrumenti imaju prednost u primjeni ispred zakona, ali ne i samog Ustava $\mathrm{BiH}$ koji - pored navedenih odredbi, sadrži i odredbe kojima se istovremeno uvodi gruba diskriminacija po etničkom osnovu - oživotvorena u principu konstitutivnosti naroda.

Kuriozitet Ustava $\mathrm{BiH}$ sastoji se i u tome što je njegov orginalni tekst sačinjen na stranom jeziku, te što nikada nije usvojen u zvaničnom prevodu u proceduri pred nadležnim predstavničkim tijelom, čime bi se odredila i pozicija Evropske konvencije po sili Ustava koja po izvornom tekstu - na stranom/ engleskom jeziku ne odgovara njenoj poziciji slabije pravne moći u odnosu na sam Ustav. Međutim, činjenica je da je tekst Ustava u momentu stupanja na snagu istovremeno sadržavao i odredbe kojima se referira na Evropsku konvenciju i njene Protokole, ali i odredbe kojima se na nivou ustavne norme uvodi gruba diskriminacija po etničkom osnovu u oblasti biračkih prava. Takvo stanje u oblasti ustavne regulative, koje izgleda haotično i u sukobu samo sa sobom, jedino se može tumačiti time što bi se odredbe Evropske konvencije i njenih Protokola mogle smatrati svojevrsnim lex generalis - opštim odredbama u odnosnu na druge odredbe koje konkretno propisuju strukturu i način izbora pojedinih institucija javne vlasti $\mathrm{BiH}$ - koje bi se, u takvom odnosu, mogle smatrati lex specialis odredbama - sa kojima se u konkretnim oblastima regulative isključuje primjena određenih odredaba Evropske konvencije i njenih Protokola opšteg karaktera - po principu lex specialis derogat legi generali.

Pri tome, međutim, treba imati u vidu da se odredba člana II/2. Ustava BiH referira na Evropsku konvenciju i njene Protokole - bez ograničenja i bilo kakvog preciziranja, što bi se moglo tumačiti da se ova odredba Ustava odnosi na one Protokole koji su u momentu stupanja na snagu Ustava $\mathrm{BiH}$ bili na pravnoj snazi, ali i na one koji su usvojeni i stupili na snagu poslije

${ }^{12}$ Zlatan Begić, Opšta načela međunarodnog prava u ustavnom sistemu Bosne i Hercegovine, 5 Anali Pravnog fakulteta u Zenici 9, 2012, str. 67-69. 
potpisivanja i stupanja na snagu Dejtonskog mirovnog sporazuma. Takvo tumačenje bi imalo smisla i s obzirom na odredbu člana X/2. kojom se zabranjuje bilo kakva izmjena Ustava $\mathrm{BiH}$ sa kojom bi se umanjio korpus ljudskih prava. U tom smislu, od posebne važnosti je Protokol 12. Evropske konvencije kojim se uvodi opšta zabrana diskriminacije obzirom na sva prava garantovana zakonom. Ovaj Protokol, između ostalog, od ključne važnosti je bio i za donošenje presuda Evropskog suda za ljudska prava u predmetima koji se odnose na povredu biračkih prava građana BiH. Ovdje je, dakle, riječ o primjeni Evropske konvencije i njenih Protokola po sili Ustava.

Međutim, BiH je u međuvremenu ratifikovala Evropsku konvenciju, uključujući i Protokol 12, čime se činom ratifikacije pravno obavezala po međunarodnom ugovornom pravu, ali i po vlastitom Ustavu na usklađivanje ukupnog pravnog poretka, uključujući i državni Ustav, kako je prethodno obrazloženo, sa odredbama ovih međunarodnih instrumenata. Ovdje je riječ o obavezi pravne naravi, čije neizvršavanje je ozbiljno dovelo u pitanje princip vladavine prava i ustavne vladavine, održavajući na snazi diskriminatorske odredbe u oblasti izbora i izbornog prava koje su odavno morale biti izmijenjene slijedeći odredbe Evropske konvencije i njenog Protokola 12., povodom čega su donesene i presude Evropskog suda za ljudska prava. ${ }^{13}$

To iako je krivičnim zakonodavstvom $\mathrm{BiH}$ neprovođenje odluka Ustavnog suda i Evropskog suda za ljudska prava inkriminisano kao krivično djelo za koje je propisana kazna od 6 mjeseci do 5 godina zatvora. Tako član 239. Krivičnog zakona BiH propisuje: „Službena osoba u institucijama Bosne i Hercegovine, institucijama entiteta ili institucijama Brčko Distrikta Bosne i Hercegovine, koja odbije da izvrši konačnu i izvršnu odluku Ustavnog suda Bosne i Hercegovine, Suda Bosne i Hercegovine, Doma za ljudska prava ili Evropskog suda za ljudska prava, ili sprječava da se takva odluka izvrši, ili na drugi način onemogućava njeno izvršenje, kaznit će se kaznom zatvora od šest mjeseci do pet godina.” Bez obzira na vrlo široku formulaciju prethodno citirane odredbe Krivičnog zakona u BiH niko nije odgovarao za neprovođenje navedenih presuda Evropskog suda za ljudska prava, iako se odgovornost za to vrlo pouzdano može objektivizirati i individualizirati obzirom na sve okolnosti.

Uslijed kršenja ove pravne obaveze koja, u konačnom, dovodi i do kršenja Ustava $\mathrm{BiH}$, od momenta ratifikacije Evropske konvencije i, posebno njenog Protokola 12, od strane države $\mathrm{BiH}$, ključne institucije javne vlasti u $\mathrm{BiH}$, Predsjedništvo BiH i Dom naroda Parlamentarne skupštine BiH (ali i

${ }^{13}$ Vidi šire o tome: Ibid., str. 62-71. 
predsjednik i dva potpredsjednika entiteta koji imaju značajne nadležnosti) biraju se u više izbornih ciklusa po propisima koji su činom ratifikacije navedenih međunarodnih instrumenata odavno trebale prestati da važe, te koje su morale biti zamijenjene odgovarajućim ustavnim i zakonskim odredbama kojima se otklanja evidentna višestruka diskriminacija potvrđena i presudama Evropskog suda za ljudska prava. Višestruka iz razloga što, prema aktuelnim ustavnim rješenjima, u oblasti biračkih prava diskriminisani su građani $\mathrm{BiH}$ koji pripadaju nacionalnim manjinama, pripadnici konstitutivnih naroda, Srbi iz entiteta Federacija BiH i Bošnjaci i Hrvati iz entiteta Republika Srpska, te građani koji ne pripadaju niti nacionalnim manjinama, niti konstitutivnim narodima, nego svoju nacionalnu pripadnost vezuju za građanski status, odnosno za pripadnost Bosni i Hercegovini kao državi (Bosanci i Hercegovci).

Dakle, suština problema Bosne i Hercegovine nije samo u problematici legitimiteta - koji je već u startu kompromitiran uvođenjem diskriminatorskih odredbi u ustavni sistem zemlje, nego je prava suština problema u legalitetu, odnosno vladavini prava u oblasti izvršavanja obaveza pravne naravi u pogledu implementacije opšte-prihvaćenih međunarodnih demokratskih standarda u oblasti izbora i izbornog prava, bez čega nema demokratskog društva i države. Umjesto potpuno opravdane i nužne diskusije po pitanju legaliteta institucija vlasti, time i čitavog ustavnog poretka, što je kvalitet koji nužno prethodi ostvarivanju demokratskog legitimiteta u svakoj demokratskoj državi u smislu principa vladavine prava, u javnom diskursu nametnut je narativ o tzv. „legitimnom predstavljanju naroda” kojim se potpuno izvrće i vulgarizira suština ovog pojma u sadržajnom, aksiološkom, ciljnom i etimološkom smislu, o čemu će više biti riječi u tekstu koji slijedi.

\section{Izborni sistem Bosne i Hercegovine, deficit legaliteta, demokratskog legitimiteta i nedemokratska teza o tzv. ,legitimnom predstavljanju"}

Jasno je da su pri ugovaranju i potpisivanju Opšteg okvirnog sporazuma za mir u BiH napravljeni brojni kompromisi na račun principa vladavine prava, principa legaliteta i demokratskog legitimiteta, a zbog uspostavljanja mira i sigurnosti kao najvišeg legitimnog cilja po međunarodnom pravu. Međutim, mir i sigurnost su uspostavljeni, a logika demokratske doktrine, princip vladavine prava, odredbe Ustava $\mathrm{BiH}$ i međunarodnih instrumenata na snazi, te eurointegracijski procesi koji, između ostalog podrazumijevaju pristupanje sporazumima međunarodnog karaktera i provođenje reformi u brojnim 
oblastima, uključujući i oblast izbora i izbornog prava, zahtijevaju eliminisanje diskriminatorskih odredbi u fazi legitimacije institucija javne vlasti, odnosno u fazi izbora. To nalaže princip legaliteta koji, kako je naprijed navedeno, u demokratskim državama prethodi kvalitetu demokratskog legitimiteta na način da, ukoliko je država demokratska, njezin pravni sistem mora da uvažava opšte-prihvaćene međunarodne demokratske standarde pravne naravi, među kojima je jednakost građana i zabrana diskriminacije u pogledu njihovih biračkih prava polazna premisa da bi se jedno društvo i država uopšte mogli smatrati demokratskim.

Po predstavkama/aplikacijama građana $\mathrm{BiH}$, kako je poznato, donesene su i presude Evropskog suda za ljudska prava u Strazburu kojima je konstatovana povreda Evropske konvencije za zaštitu ljudskih prava i temeljnih sloboda i pojedinih njenih Protokola u vezi sa povredom biračkih prava građana, odnosno nemogućnosti kandidature za Dom naroda Parlamentarne skupštine i Predsjedništvo $\mathrm{BiH}$ zbog diskriminacije po etničkom osnovu. U predmetima Sejdić-Finci protiv BiH i Zornić protiv BiH Evropski sud je utvrdio povredu biračkih prava zbog nemogućnosti kandidovanja za Dom naroda i Predsjedništvo BiH, te povredu člana 14. Evropske konvencije u vezi sa članom 3. Protokola 1. i člana 1. Protokola 12, a u predmetu Pilav protiv $\mathrm{BiH}$ povredu biračkog prava u pogledu nemogućnosti kandidovanja za poziciju člana Predsjedništva $\mathrm{BiH}$ te, s tim u vezi, člana 1. Protokola 12. Evropske konvencije. Nakon toga, donesene su još dvije presude Evropskog suda u sličnim predmetima.

Naime, kako je poznato, članom IV/1. Ustava BiH utvrđeno da se Dom naroda Parlamentarne skupštine $\mathrm{BiH}$ sastoji od 15 delegata, pri čemu se po pet delegata iz reda hrvatskog i bošnjačkog naroda bira sa teritorije Federacije $\mathrm{BiH}$, dok se pet delegata iz reda srpskog naroda bira sa teritorije entiteta RS. ${ }^{14}$ Članom V Ustava BiH utvrđeno je da se član Predsjedništva BiH iz reda srpskog naroda bira neposredno sa teritorije entiteta RS, dok se članovi Predsjedništva $\mathrm{BiH}$ iz reda hrvatskog i bošnjačkog naroda neposredno biraju sa teritorije entiteta Federacija $\mathrm{BiH} .{ }^{15}$ Već na prvi pogled jasno je da su

\footnotetext{
${ }^{14}$ ČlanomIV/1.UstavaBiHpropisanoje,kakoslijedi:,Domnarodasesastojiod15delegata,odkojihsudvije trećine iz Federacije (uključujući pet Hrvata i pet Bošnjaka) i jedna trećina iz Republike Srpske (pet Srba). a) Nominovane hrvatske, odnosno bošnjačke delegate iz Federacije biraju hrvatski odnosno bošnjački delegati u Domu naroda Federacije. Delegate iz Republike Srpske bira Narodna skupština Republike Srpske. b) Devet članova Doma naroda sačinjava kvorum, pod uslovom da su prisutna najmanje tri bošnjačka, tri hrvatska i tri srpska delegata."

${ }^{15}$ Članom V Ustava BiH propisano je, kako slijedi: „Predsjedništvo Bosne i Hercegovine se sastoji od tri člana: jednog Bošnjaka i jednog Hrvata, koji se svaki biraju neposredno sa teritorije Federacije, i jednog Srbina, koji se bira neposredno sa teritorije Republike Srpske.”
} 
ovakvim ustavnim rješenjima u diskriminatorski položaj u pogledu biračkih prava, koja su ključna u fazi demokratske legitimacije javne vlasti, dovedeni pripadnici nacionalnih manjina, ali i pripadnici konstitutivnih naroda - Srbi iz entiteta Federacija BiH, te Hrvati i Bošnjaci iz entiteta Republika Srpska, kao i oni građani koji ne pripadaju ni nacionalnim manjinama, niti konstitutivnim narodima nego svoju nacionalnu pripadnost vezuju za građanski status, odnosno za državnu pripadnost u nacionalnom smislu (Bosanci i Hercegovci).

Nakon što je i Evropski sud za ljudska prava, donošenjem presuda u konkretnim naprijed navedenim predmetima, upozorio na kršenje Evropske konvencije i njenih Protokola koje je BiH ratifikovala, to nije uticalo na vladajuće političke subjekta da na institucionalan način omoguće provođenje pravne obaveze na usaglašavanje unutrašnjeg pravnog poretka sa preuzetim obavezama. U stvari, sa stanovišta problematike legaliteta i legitimiteta, moglo bi se konstatovati da je ustavni poredak i sistem institucija vlasti u BiH imao kvalitet legaliteta - sve do čina ratifikacije Evropske konvencije i njenih Protokola - posebno Protokola 12., odnosno nakon stupanja na pravnu snagu ovog Protokola. Nakon čina ratifikacije ovih međunarodnih instrumenata, kvalitet legaliteta se izgubio upravo iz razloga što se procedura izbora na navedene - ključne funkcije javne vlasti obzirom na njihove nadležnosti i značaj nastavila provoditi po odredbama koje su trebale prestati da važe, odnosno koje su morale biti izmijenjene i usklađene sa preuzetim obavezama iz navedenih međunarodnih instrumenata. Kako je naprijed obrazloženo, time su prekršene i odredbe Ustava BiH koje se referiraju na opšta načela međunarodnog prava i demokratske principe, pa se postavlja pitanje i pasivnosti OHR-a u tom smislu, budući da je nesumnjivo riječ i o kršenju Opšteg okvirnog sporazuma za mir u BiH, odnosno njegovog Aneksa 4. Dakle, neprovođenje obaveza iz ratifikovanih međunarodnih sporazuma/instrumenata, po samom Ustavu $\mathrm{BiH}$, ujedno predstavlja kršenje navedenog mirovnog sporazuma.

Međutim, za razliku od legaliteta koji je postojao u jednom periodu do čina ratifikacije, odnosno stupanja na pravnu snagu navedenih međunarodnih instrumenata koji nameću konkretne obaveze pravne naravi, ustavni poredak i sistem institucija u cjelokupnoj fazi „dejtonske” $\mathrm{BiH}$ nikada nije posjedovao kvalitet demokratskog legitimiteta. To, upravo iz razloga što je uspostavljen na normama diskriminatorske naravi koje su jednostavno nespojive sa samim pojmom legitimiteta i legitimne vlasti u demokratskom smislu, koja dozvolu za vladanje stiče u proceduri demokratskih izbora u kojima treba da participiraju građani sa jednakim aktivnim i pasivnim biračkim pravom, bez razlike s obzirom na bilo kakvu okolnost ili svojstvo i bez diskriminacije po bilo 
kojem osnovu. U stvari, rješavanje pitanja legaliteta sistema institucija javne vlasti u smislu usklađivanja ustavnog poretka sa obavezama pravne naravi, što uključuje i obavezu provođenja presuda Evropskog suda za ljudska prava, ujedno bi riješilo i pitanje demokratskog legitimiteta institucija javne vlasti.

Suprotno tome, bilo kakav pokušaj provođenja ovih obaveza pravne naravi blokiran je i onemogućen od strane političkih subjekata kojima u suštini odgovara posebno pozicioniranje konstitutivnih naroda u ključnim institucijama sistema, pogotovo u Domovima naroda na državnom nivou i na nivou entiteta Federacija $\mathrm{BiH}$, te koje putem tih institucija apsolutno kontrolišu proces institucionalnog odlučivanja u BiH. Nacionalističkim politikama, čije korijene treba tražiti u velikodržavnim politikama iz devedesetih godina prošlog stoljeća i teritorijalnim pretenzijama, itekako odgovara vezivanje etničkog i entitetskog/teritorijalnog predstavljanja, a što dovodi do diskriminacije čak i pripadnika konstitutivnih naroda - kako je to utvrđeno presudom Evropskog suda za ljudska prava u predmetu Pilav protiv BiH. U stvari, aktuelne vladajuće realpolitike, koje slijede koncept daljih podjela i teritorijalizacije etničkih interesa na pojedinim dijelovima $\mathrm{BiH}$, nisu zainteresirane za građane koji pripadaju konstitutivnim narodima koje nominalno predstavljaju, a koji žive na dijelovima teritorija $\mathrm{BiH}$ gdje određena politička partija koja je samoproglasila monopol na predstavljanje određenog konstitutivnog naroda ne vrši vlast ili ne predstavlja značajniji faktor, te gdje taj narod ne predstavlja matematičku većinu. Šta više, nosioci takvih politika te građane označavaju kao nelegitimne predstavnike naroda kojem, inače, pripadaju u slučaju da su izabrani na određene funkcije javne vlasti, a u posljednje vrijeme se plasira i teza o tzv. "autentičnim" pripadnicima pojedinih naroda. Po ovom konceptu, "autentični” predstavnici naroda su samo oni koji glasaju za političku partiju koja je samoproglasila monopol na političko predstavljanje određenog konstitutivnog naroda te koji, obavezno, žive na dijelovima teritorija BiH gdje taj narod predstavlja matematičku većinu.

Tako je, između ostalog, lansirana i ideja o tzv. „legitimnom predstavljanju" koja, uz zadržavanje postojećih oblika diskriminacije, podrazumijeva uvođenje novih oblika diskriminacije na drugim nivoima organizacije vlasti, sa težnjom ka daljoj teritorijalizaciji etničkih interesa. To bi, ujedno vodilo daljem kršenju Ustava BiH u kontekstu obaveza pravne naravi iz Evropske konvencije i njenih Protokola i drugih ratifikovanih međunarodnih instrumenata/sporazuma i daljem narušavanju principa legaliteta i vladavine prava, te do dalje delegitimacije sistema institucija javne vlasti i čitavog ustavnog 
poretka sa stanovišta opšte-prihvaćenih međunarodnih demokratskih standarda pravne naravi.

Na toj liniji bio je i prijedlog Zakona o izmjenama i dopunama Izbornog zakona BiH koji su zagovornici politika tzv. "legitimnog predstavljanja" dostavili u parlamentarnu proceduru na usvajanje po hitnom postupku, nakon donošenja odluke Ustavnog suda BiH u predmetu U-23/14, koji je kolokvijalno poznat kao "predmet Ljubić" po podnosiocu zahtjeva za ocjenu ustavnosti. Odlukom donesenom u predmetu U-23/14, član 10.12 stav 2. u dijelu u kojem propisuje: „Svakom konstitutivnom narodu se daje jedno mjesto u svakom kantonu" i član 20.12 A stav 2. tačke a) - j) Izbornog zakona BiH proglašeni su neustavnim. Delegati Doma naroda Parlamenta Federacije BiH delegirali su se iz kantonalnih skupština upravo u skladu s navedenim odredbama koje su oglašene neustavnim i koje su prestale da važe. Riječ je o odredbama Izbornog zakona BiH koje su predviđale da će se iz svake kantonalne skupštine/kantona delegirati najmanje jedan delegat iz reda svakog konstitutivnog naroda (ako je takav izabran u kantonalnu skupštinu) - (član 10.12 stav 2. Izbornog zakona), te odredbama člana 20.16 A stav 2. tačke a-j. ${ }^{16}$ koji je propisivao tačan broj delegata Bošnjaka, Hrvata, Srba i „Ostalih” koji će biti delegirani iz svake kantonalne skupštine u Dom naroda Parlamenta Federacije $\mathrm{BiH}$. Poseban problem za nosioce politike tzv. "legitimnog predstavljanja" bio je dio odredbe člana 10.12 stav 2. Izbornog zakona BiH kojim je bilo propisano da se delegati sva tri konstitutivna naroda delegiraju u Dom naroda

\footnotetext{
${ }^{16}$ Ovim članom bilo je propisano, kako slijedi: „Do organiziranja novog popisa, kao osnov koristi se popis iz 1991. godine tako da svaki kanton bira sljedeći broj delegata: a) iz zakonodavnog tijela Kantona br. 1, Unsko-sanski kanton, bira se pet delegata, uključujući dva iz reda bošnjačkog, jednog iz reda hrvatskog i dva iz reda srpskog naroda; b) iz zakonodavnog tijela Kantona br. 2, Posavski kanton, biraju se tri delegata, uključujući jednog iz reda bošnjačkog, jednog iz reda hrvatskog i jednog iz reda srpskog naroda; c) iz zakonodavnog tijela Kantona br. 3, Tuzlanski kanton, bira se osam delegata, uključujući tri iz reda bošnjačkog, jednog iz reda hrvatskog, dva iz reda srpskog naroda i dva iz reda ostalih; d) iz zakonodavnog tijela Kantona br. 4, Zeničko-dobojski kanton, bira se osam delegata, uključujući tri iz reda bošnjačkog, dva iz reda hrvatskog, dva iz reda srpskog naroda i jednog iz reda ostalih; e) iz zakonodavnog tijela Kantona br. 5, Bosansko-podrinjski kanton - Goražde, biraju se tri delegata, uključujući jednog iz reda bošnjačkog, jednog iz reda hrvatskog i jednog iz reda srpskog naroda; f) iz zakonodavnog tijela Kantona br. 6, Srednjobosanski kanton, bira se šest delegata, uključujući jednog iz reda bošnjačkog, tri iz reda hrvatskog, jednog iz reda srpskog naroda i jednog iz reda ostalih; g) iz zakonodavnog tijela Kantona br. 7, Hercegovačko-neretvanski kanton, bira se šest delegata, uključujući jednog iz reda bošnjačkog, tri iz reda hrvatskog, jednog iz reda srpskog naroda i jednog iz reda ostalih; h) iz zakonodavnog tijela Kantona br. 8, Zapadnohercegovački kanton, biraju se četiri delegata, uključujući jednog iz reda bošnjačkog, dva iz reda hrvatskog i jednog iz reda srpskog naroda; i) iz zakonodavnog tijela Kantona br. 9, Kanton Sarajevo, bira se 11 delegata, uključujući tri iz reda bošnjačkog, jednog iz reda hrvatskog, pet iz reda srpskog naroda i dva iz reda ostalih i j) iz zakonodavnog tijela Kantona br. 10, Kanton 10, biraju se četiri delegata, uključujući jednog iz reda bošnjačkog, dva iz reda hrvatskog i jednog iz reda srpskog naroda."
} 
Federalnog parlamenta iz svake kantonalne skupštine/kantona čime se, zapravo, omogućavalo ostvarivanje pasivnog biračkog prava onih koji pripadaju konstitutivnim narodima da budu kandidati za ovu poziciju pod uvjetom da su izabrani u skupštine kantona.

Na sjednici Ustavnog suda $\mathrm{BiH}$, održanoj 6. jula 2017., konstatovano je da Parlamentarna skupština BiH nije uskladila odredbe Izbornog zakona BiH koje je Ustavni sud Odlukom u slučaju U-23/14 proglasio neustavnim. Iz tog razloga Ustavni sud je odlučio da se ove odredbe stavljaju van snage.

Inače, Odluka Ustavnog suda $\mathrm{BiH}$ br. U-23/14 predmet je politiziranja i tumačenja koja nemaju osnova, upravo od strane zagovornika teze o tzv. "legitimnom predstavljanju" koji su pokušali ovu Odluku iskoristiti za utemeljenje ove svoje teze. Međutim, značajno je naglasiti, da su kojim slučajem provedene obaveze iz Evropske konvencije i njenih Protokola i drugih ratifikovanih međunarodnih instrumenata/sporazuma, kao i presude Evropskog suda za ljudska prava po vremenskom redoslijedu nastanka pravne obaveze, što je nužno podrazumijevalo i ustavnu reformu, donošenje Odluke u predmetu U-23/14 iz 2016. godine uopšte ne bi bilo moguće.

Nakon ove Odluke, kojom je kreirana pravna praznina u pogledu načina popunjavanja Doma naroda Parlamenta Federacije BiH, jer su neustavnim oglašene odredbe koje su propisivale formulu za popunjavanje ovog Doma u smislu raspodjele delegatskih mjesta po kantonima, nosioci politike tzv. "legitimnog predstavljanja" podnijeli su prijedlog Zakona o izmjenama i dopunama Izbornog zakona BiH. Ovim prijedlogom bilo je predviđeno da se delegati Doma naroda Parlamenta Federacije BiH iz reda hrvatskog konstitutivnog naroda delegiraju iz sedam kantona (Hercegovačko-neretvanski, Srednjebosanski, Zapadnohercegovački, Zeničko-dobojski, Tuzlanski, Posavski kanton i Kanton 10), dok građani koji pripadaju hrvatskom konstitutivnom narodu iz preostala tri kantona ne bi imali pravo da budu kandidati za ovu funkciju, bez obzira na mogućnost da su izabrani u odnosne kantonalne skupštine. Pri tome se ukupno 11 od 17 delegata trebalo delegirati iz kantona od kojih u 4 kantona HDZ tradicionalno ima apsolutnu vlast (Hercegovačkoneretvanski, Zapadnohercegovački, Posavski kanton i Kanton 10). Najmanje još jedno delegatsko mjesto, koje je neophodno za ostvarivanje apsolutne kontrole nad ovim Domom, imajući u vidu da jedna trećina delegata iz reda svakog konstitutivnog naroda ima pravo da predlaže kandidate za predsjednika i potpredsjednike Federacije $\mathrm{BiH}$ - čime se omogućava i formiranje Vlade Federacije $\mathrm{BiH}, \mathrm{HDZ}$ bi pod aktuelnim političkim okolnostima lako ostvario u jednom od preostala tri kantona. To pogotovo u Srednjebosanskom kantonu 
iz kojeg su se prema ovom prijedlogu izmjena i dopuna Izbornog zakona trebala delegirati 4 delegata Hrvata za Dom naroda entiteta Federacija BiH u kojem pored oko 150 hiljada Bošnjaka, živi i oko 100 hiljada Hrvata i gdje HDZ tradicionalno i zasnovano na višedecenijskoj kontroli svih resursa ostvaruje dobar izborni rezultat, te tradicionalno predstavlja jedan od ključnih političkih faktora. Pri tome je ovakva raspodjela delegatskih mjesta još zanimljivija ukoliko se uporedi sa raspodjelom bošnjačkih delegatskih mjesta po ovom prijedlogu, te sa etničkom strukturom stanovništva u pojedinim kantonima, što inače predstavlja dugogodišnji problem u smislu postojanja očitog debalansa između delegatskih mjesta i etničke strukture stanovništva kantona još od stupanja na snagu aktuelnih ustavnih i drugih rješenja s tim u vezi.

Tako npr., iako u Hercegovačko-neretvanskom kantonu, prema posljednjem popisu stanovništva živi 92005 Bošnjaka i 118297 Hrvata, navedenim prijedlogom bilo je utvrđeno da se iz ovog kantona delegira pet delegata iz reda hrvatskog konstitutivnog naroda, a samo jedan iz reda bošnjačkog konstitutivnog naroda. Dalje, u Srednjebosanskom kantonu prema posljednjem popisu stanovništva živi 146652 Bošnjaka i 97629 Hrvata, a ovim prijedlogom bilo je utvrđeno da se iz ovog kantona delegiraju četiri delegata Hrvata za Dom naroda Parlamenta Federacije BiH, a samo jedan delegat iz reda bošnjačkog naroda, iako bošnjački konstitutivni narod predstavlja većinu u ovom kantonu!? Inače, ustavna pozicija federalnog Doma naroda i način raspodjele delegatskih mjesta po kantonima, još od stupanja na snagu aktuelnih ustavnih i drugih rješenja u privilegovan položaj dovodi HDZ, gdje izborni rezultat ima drugorazredni značaj. U stvari, na ovaj način, HDZ je navedenim prijedlogom izmjena i dopuna Izbornog zakona želio još više ojačati stranačke pozicije. Međutim, ovim je ujedno negirana teza o tzv. "legitimnom predstavljanju naroda" - jer je ona prosto neizvodiva obzirom na jednako pravo drugih naroda, osim ako se tzv. "legitimno predstavljanje" jednog naroda - u režiji kreatora ovog koncepta ne namjerava ostvarivati na račun jednakosti drugih konstitutivnih naroda i njihovog predstavljanja. Pri tome, nije bez značaja i to što HDZ Srednjebosanski i posebno Hercegovačko-neretvanski kanton vidi kao okosnicu tzv. „trećeg entiteta” u kojem se nalazi i Grad Mostar koji, prema ovom konceptu treba da bude, stolni - glavni grad tzv. „trećeg entiteta”, iako je riječ o gradu u kojem u podjednakom broju žive i Hrvati i Bošnjaci, te građani druge etničke pripadnosti o određenom broju.

Prema ovom prijedlogu izmjena i dopuna Izbornog zakona, delegati iz reda bošnjačkog i srpskog naroda u Domu naroda trebali su se delegirati također iz sedam kantona, dok u tri kantona građani BiH koji pripadaju ovim 
narodima ne bi imali pravo da budu kandidati za ovu funkciju čak i ukoliko su izabrani u odnosna kantonalna predstavnička tijela/skupštine. Delegati iz reda „Ostalih” u Domu naroda federalnog Parlamenta prema ovom prijedlogu trebali su biti delegirani iz četiri kantona, dok u ostalih šest kantona ovi građani BiH ne bi imali pravo kandidature za ovu funkciju bez obzira na moguću okolnost da su izabrani na neposrednim izborima na poziciju zastupnika $\mathrm{u}$ odnosnim kantonalnim skupštinama.

Sasvim je jasno da su ovakve intencije u direktnoj koliziji sa opšte-prihvaćenim međunarodnim demokratskim standardima koji se tiču jednakosti biračkih prava građana, te u suprotnosti sa već donesenim presudama Evropskog suda za ljudska prava. Eventualnim usvajanjem i stupanjem na snagu ovakvih i sličnih prijedloga nastala bi slična - ako ne i identična pravna situacija kao u slučaju Pilav protiv BiH. U slučaju Pilav, Evropski sud za ljudska prava konstatovao je povredu pasivnog biračkog prava građanina $\mathrm{BiH}$ Ilijaza Pilava koji nije mogao biti kandidat za funkciju člana Predsjedništva $\mathrm{BiH}$ iz razloga što je po svojoj etničkoj pripadnosti Bošnjak sa mjestom prebivališta u entitetu RS, a imajući u vidu da se prema Ustavu BiH članovi Predsjedništva iz reda bošnjačkog i hrvatskog konstitutivnog naroda biraju sa teritorije entiteta Federacija $\mathrm{BiH}$, dok se sa teritorije entiteta RS bira član Predsjedništva iz reda srpskog konstitutivnog naroda. Prethodno navedenim prijedlogom HDZ-a uveo bi se konceptualno dosta sličan, ali ipak novi oblik diskriminacije, s tom razlikom što bi se diskriminacija po etničkom osnovu uvela s obzirom na kanton u kojem građani imaju prebivalište a u pogledu mogućnosti kandidature za predstavničko tijelo - Dom naroda Parlamenta Federacije BiH. Ovaj prijedlog, međutim, nije usvojen.

U pogledu moguće stvarne namjere podnosioca zahtjeva za ocjenu ustavnosti u predmetu br. U-23/14 - g-dina Bože Ljubića, koji je jedan od najupornijih zagovornika politike tzv. "legitimnog predstavljanja" i uspostavljanja tzv. "trećeg entiteta", važno je ukazati na činjenicu koja se u javnosti uglavnom zanemaruje. Naime, Ustavni sud BiH predmetni Zahtjev za ocjenu ustavnosti je djelimično usvojio. Ustavni sud $\mathrm{BiH}$ je odbio Zahtjev za ocjenu ustavnosti u ovom predmetu gdje je podnosilac Zahtjeva osporavao ustavnost odredbe člana 10.12 Izbornog zakona BiH u dijelu koji, između ostalog, propisuje nadležnost Centralne izborne komisije $\mathrm{BiH}$ da, nakon svakog popisa stanovništva, utvrdi raspodjelu delegatskih mjesta po kantonima za Dom naroda Parlamenta Federacije BiH. ${ }^{17}$

${ }^{17}$ Odredba Izbornog zakona $\mathrm{BiH}, \mathrm{u}$ tom smislu, propisuje: „Centralna izborna komisija BiH određuje,
nakon svakog popisa, broj delegata koji se biraju iz svakog konstitutivnog naroda i iz reda ostalih, a koji 
U situaciji kada su prestale da važe odredbe Izbornog zakona BiH kojima je propisana formula za konstituisanje Doma naroda Parlamenta Federacije $\mathrm{BiH}$, dakle u slučaju nastajanja pravne praznine u tom pogledu, imajući u vidu efikasne mehanizme blokade kojima nosioci politika daljih podjela u $\mathrm{BiH}$ objektivno raspolažu, namjeravala se oduzeti nadležnost Centralnoj izbornoj komisiji BiH da propiše formulu raspodjele delegatskih mjesta po kantonima za Dom naroda federalnog Parlamenta, pod okolnostima blokade nadležnog državnog zakonodavnog tijela u smislu donošenja adekvatnih normi kojima bi se popunila pravna praznina nastala na ovaj način.

Pri tome valja imati u vidu da je Dom naroda Parlamenta Federacije $\mathrm{BiH}$ ključno tijelo u proceduri formiranja vlasti u $\mathrm{BiH}$. To iz razloga što se bez federalnog Doma naroda ne može konstituisati državna zakonodavna vlast jer delegate Bošnjake i delegate Hrvate državnog Doma naroda Parlamentarne skupštine $\mathrm{BiH}$ delegiraju odgovarajući klubovi federalnog Doma naroda. Ovdje, između ostalog, treba imati u vidu poziciju i nadležnosti državnog Doma naroda koji je ravnopravan Predstavničkom domu - što, pored ostalog, znači da svaki zakon na državnom nivou mora biti usvojen u oba Doma u istovjetnom tekstu. Osim toga, bez federalnog Doma naroda nije moguće konstituisanje niti federalne izvršne vlasti, budući da se upravo u ovom Domu utvrđuje prijedlog kandidata za funkciju predsjednika i dva potpredsjednika Federacije $\mathrm{BiH}-$ koji, nakon procedure izbora, imenuju Vladu Federacije BiH. Bez federalnog Doma naroda ne može se konstituisati niti zakonodavna vlast Federacije $\mathrm{BiH}$ budući da je Parlament Federacije dvodomno predstavničko tijelo u kojem donošenje bilo kojeg zakona zahtijeva potvrdu oba Doma u istom tekstu.

Dakle, nepostojanje formule za raspodjelu delegatskih mjesta u federalnom Domu naroda, te ukidanje zakonske nadležnosti Centralne izborne komisije $\mathrm{BiH}$ da popuni nastalu pravnu prazninu oglašavanjem neustavnom odredbe Izbornog zakona koja predviđa takvu mogućnost, vrlo lako je moglo dovesti do stanja potpune blokade sistema, što je podnosilac Zahtjeva za ocjenu ustavnosti u ovom predmetu morao da zna, štaviše - po prirodi stvari uopšte nije vjerovatno da to nije imao u vidu. Inače, političke opcije koje su zagovornici teze o tzv. "legitimnom predstavljanju" poznate su po blokadama institucija vlasti kojima žele ishoditi političke ustupke. Pored gotovo svakodnevnih blokada institucija države i entiteta Federacija $\mathrm{BiH}$, poznata je i blokada koja je također bila usmjerena na onemogućavanje konstituisanja Doma naroda Parlamenta Federacije BiH poslije opštih izbora 2010. godine. Tada su

se biraju iz zakonodavnog tijela svakog kantona.” 
pojedine kantonalne Skupštine u kojima je HDZ imao dominantnu poziciju odbile da provedu postupak delegiranja članova ovog Doma u propisanim rokovima, zbog nezadovoljstva izbornim rezultatima. Pod takvim okolnostima morao je intervenisati visoki predstavnik, kako bi spriječio potpunu blokadu $\mathrm{u}$ implementaciji izbornih rezultata i konstituisanje institucija javne vlasti. Za razliku od ovog slučaja grube političke blokade, koja je bila praćena kršenjem ustavnih i drugih pozitivno-pravnih normi, blokada proizašla iz Odluke Ustavnog suda BiH po Zahtjevu za ocjenu ustavnosti u predmetu "Ljubić" trebala je nastupiti u skladu sa ovom Odlukom Ustavnog suda. Time bi se izbjegla lična i kolektivna politička i druga odgovornost političkih subjekata i njihovih rukovodstava za nove oblike čisto političkih blokada.

Osim toga, Bosna i Hercegovina je zemlja u kojoj izbornog pobjednika ne određuju građani na izborima, nego je izborni pobjednik tj. onaj politički subjekt koji ima presudan politički značaj i ključni uticaj - prvo na implementaciju izbornih rezultata i formiranje vlasti - a potom i na proces odlučivanja, unaprijed određen nekonsekventnim ustavnim rješenjima uključujući i procedure odlučivanja - što je posebna tema, izbornom geometrijom te, kako pokazuje posljednji slučaj, čak i odlukama državnih organa. S tim u vezi, a imajući u vidu posebnu poziciju federalnog Doma naroda, valja ukazati na formulu za raspodjelu delegatskih mjesta iz reda konstitutivnih naroda i "Ostalih" koja je utvrđena odlukom Uputstvom Centralne izborne komisije BiH u nemogućnosti donošenja izmjena i dopuna Izbornog zakona $\mathrm{BiH}$ povodom Odluke Ustavnog suda $\mathrm{BiH}$ u predmetu U-23/14, radi postojanja brojnih mehanizama blokade.

Kako će se vidjeti iz teksta koji slijedi, raspodjelom ovih mjesta za federalni Dom naroda zapravo su, na neki način poništeni rezultati izbora, pa je politički subjekat (HDZ i druge manje stranke okupljene oko HDZ-a) koji uživa podršku od oko svega $7 \%$ od ukupnog biračkog tijela, odnosno oko $13 \%$ od izašlih na izbore u entitetu Federacija BiH promovisan u dominantnu političku opciju, bez koje nije moguće implementirati izborne rezultate i formirati vlast na nivou entiteta Federacija $\mathrm{BiH}$ u skladu sa izbornim rezultatima, što je inače prisutno stanje zbog ustavnih i drugih rješenja već dugi niz godina. Dakle, pozicija federalnog Doma naroda i način popunjavanja, odnosno način raspodjele delegatskih mjesta po kantonima oduvijek je predstavljao problem u smislu konsekventnog predstavljanja konstitutivnih naroda u ovom tijelu s obzirom na strukturu stanovništva u kantonima. Zapravo, imajući u vidu etničku strukturu stanovništva u kantonima, vezivanje etničkog predstavljanja za teritorijalno predstavljanje, brojnost pojedinih etničkih skupina, te ustavnu obavezu paritetnog predstavljanja konstitutivnih naroda u federalnom Domu 
naroda, to dovodi do toga da je vrlo teško, ako ne i nemoguće u matematičkom smislu napraviti takav izračun raspodjele delegatskih mjesta po kantonima a da se pri tome ozbiljno ne dovede u pitanje adekvatno predstavljanje svih konstitutivnih naroda i građana, odnosno njihova ravnopravnost. To samo po sebi govori o neadekvatnosti aktuelnih ustavnih rješenja koja su uzrok takvog stanja. Takva pozicija HDZ-a u federalnom Domu naroda, posebno imajući u vidu ustavnu poziciju ovog Doma i njegove nadležnosti zasnovano na ustavnim rješenjima, a potom i raspodjelu delegatskih mjesta po kantonima u dugogodišnjem periodu, otvorila je mogućnost za konstantne i otvorene političke ucjene još od stupanja na snagu aktuelnih ustavnih i drugih rješenja. To je u posljednje vrijeme kulminiralo u pravcu zahtjeva za donošenja Izbornog zakona koji bi omogućio nedemokratski tzv. koncept „legitimnog predstavljanja", čime se uslovljava deblokada implementacije izbornih rezultata iz 2018. godine, izbor predsjednika i potpredsjednika Federacije BiH i formiranje nove federalne Vlade u skladu sa izbornim rezultatima.

Tako je, primjera radi, i Uputstvom CIK-a utvrđeno da se u Hercegovačkoneretvanskom kantonu delegiraju tri delegata Hrvata, dva delegata iz reda srpskog naroda, te jedan delegat Bošnjak, iako u ovom kantonu prema posljednjem popisu živi 92.005 Bošnjaka, 118.297 Hrvata i 6.432 Srba. Iz Srednjebosanskog kantona, u kojem prema posljednjem popisu živi 146652 Bošnjaka, 97629 Hrvata i 3043 Srba, prema Uputstvu CIK-a delegira se jedan delegat iz reda bošnjačkog, tri iz reda hrvatskog i jedan iz reda srpskog konstitutivnog naroda (uz jednog delegata iz reda Ostalih). Već na prvi pogled uočljiv je nesrazmjerno veliki debalans između broja delegatskih mjesta i broja pripadnika konstitutivnih naroda u ovim kantonima, odnosno stvarne strukture stanovništva, pa se npr. opravdano može postaviti pitanje očiglednog deficita u pogledu "legitimnog predstavljanja" Bošnjaka pod takvim okolnostima, što je stanje koje je i ranije bilo prisutno. Zapravo, nedemokratski tzv. koncept "legitimnog predstavljanja" jednog naroda, prema nosiocima ovog projekta, očigledno podrazumijeva proširivanje već prisutne višestruke ispodpredstavljenost drugih naroda, uz sva druga kršenja biračkih prava građana i opšte-prihvaćenih međunarodnih demokratskih standarda pravne naravi, kako je naprijed obrazloženo.

Na ovaj način, zahvaljujući aktuelnim ustavnim rješenjima na prvom mjestu - a potom i odluci/Uputstvu CIK-a u posljednjem slučaju, zapravo se obesmišljavaju izbori i demokratski standardi, te se pobjednik izbora - bez obzira na izborni rezultat može unaprijed sa sigurnošću pretpostaviti, ako se pobjednikom izbora može smatrati (a može!), između ostalog, onaj subjekt 
koji je ključ za implementaciju rezultata izbora. Tako, zahvaljujući nekonsekventnim aktuelnim ustavnim rješenjima u $\mathrm{BiH}$ je nedvosmisleno uspostavljena vlast političke manjine nad političkom većinom, u ovom i drugim slučajevima, bez obzira na rezultate izbora.

Tako je osigurana prevlast HDZ-a i drugih manjih partija okupljenih oko HDZ-a u Domu naroda, pri čemu u ovom tijelu, zahvaljujući raspodjeli delegatskih mjesta za Dom naroda po kantonima, nije moguće osigurati najmanje 1/3 delegata iz reda hrvatskog naroda koji pripadaju političkim opcijama građanske orijentacije, a koja trećina je neophodna kako bi se utvrdio prijedlog za izbor predsjednika i dva potpredsjednika Federacije BiH koji imenuju premijera i Vladu Federacije BiH. Time je omogućeno političkim subjektima koji uživaju podršku svega 7\% građana od ukupnog biračkog tijela u entitetu Federacija $\mathrm{BiH}$ da blokiraju implementaciju izbornih rezultata i uspostavu vlasti više od dvije godine nakon opštih izbora 2018. godine, uslovljavajući deblokadu usvajanjem Izbornog zakona kojim bi se proveo njihov politički koncept tzv. "legitimnog predstavljanja", koncept daljih podjela, uvođenja novih oblika diskriminacije i stvaranja preduvjeta za uspostavu tzv. „trećeg entiteta" na dijelovima teritorija $\mathrm{BiH}$ pod dominacijom HDZ-a.

$\mathrm{Da}$ je Centralna izborna komisija $\mathrm{BiH}$ utvrdila raspodjelu delegatskih mandata po kantonima na drugačiji način, što je opravdano mogla učiniti s obzirom na strukturu stanovništva te da je, u skladu sa objektivnim kriterijima, pojedina delegatska mjesta rasporedila u kantone u kojima HDZ tradicionalno među Hrvatima i građanima nema značajniju podršku, to je moglo otvoriti mogućnost građanima $\mathrm{BiH}$, zastupnicima kantonalnih skupština iz reda hrvatskog naroda koji pripadaju drugim političkim opcijama građanske orijentacije za eventualni izbor i članstvo u Domu naroda Parlamenta Federacije BiH. Time bi se mogla osigurati najmanje jedna trećina delegata iz reda sva tri konstitutivna naroda koja ne bi bila podložna zahtjevima za blokadu implementacije izbornih rezultata u cilju iznude političkih ustupaka suprotnih normama ustavne naravi, opšte-prihvaćenim međunarodnim demokratskim standardima, kao i presudama Evropskog suda za ljudska prava. ${ }^{18}$ Međutim, ključni problem je

\footnotetext{
${ }^{18}$ Prilikom donošenja predmetnog Uputstva Centralne izborne komisije $\mathrm{BiH}$, između ostalih pitanja i kriterija raspodjele delegatskih mjesta objektivne naravi, postavilo se pitanje s obzirom na koji popis stanovništva bi valjalo utvrditi raspodjelu delegatskih mandata za federalni Dom naroda po kantonima, budući da Izborni zakon $\mathrm{BiH}$ propisuje da Centralna izborna komisija $\mathrm{BiH}$ određuje, nakon svakog popisa, broj delegata koji se biraju iz svakog konstitutivnog naroda i iz reda ostalih iz zakonodavnih tijela kantona. Prostim jezičkim tumačenjem ove odredbe moglo bi se zaključiti da se formula raspodjele delegatskih mjesta za federalni Dom naroda treba utvrditi prema popisu stanovništva iz 2013. godine, iz razloga što je to posljednji popis koji je proveden u BiH u vremenskom smislu. Ali, Ustav entiteta Federacija BiH, kao poseban ustavni princip, propisuje obavezu proporcionalne zastupljenosti
} 
ipak u nekonsekventnim ustavnim i drugim rješenjima koja su omogućavala (i dalje omogućavaju!) takvo stanje već duži vremenski period.

Osim toga, nedemokratski politički koncept tzv. „legitimnog predstavljanja" po svojoj suštini potpuno dovodi u pitanje legitimitet delegata iz reda srpskog naroda, onako kako ga predstavljaju nosioci ovog projekta. To iz razloga što ne postoji kanton u entitetu Federacija BiH u kojem srpski konstitutivni narod predstavlja većinu ili u kojem su pripadnici ovog naroda zastupljeni u značajnijem broju, pa bi po logici zagovornika tzv. ,legitimnog predstavljanja" nelegitimni bili i svi delegati iz reda srpskog naroda na funkcijama delegata federalnog Doma naroda i na drugim funkcijama javne vlasti, budući da je jasno da su pretežno izabrani glasovima građana koji ne pripadaju srpskom konstitutivnom narodu. Jasno je da je riječ o potpunoj vulgarizaciji pojma legitimiteta, koji je izvorno kategorija demokratske naravi i sadržaja, koja ne podnosi nejednakost, diskriminaciju, negiranje prava na obavljanje javnih funkcija po osnovu etničke pripadnosti ili zabranu glasanja za kandidate koji ne pripadaju istoj etničkoj skupini kojoj pripada građanin-birač. Na koncu, hipotetski, čak ukoliko bi nosioci ovog nedemokratskog koncepta uspjeli u svojim namjerama, a što nije vjerovatno, postavlja se pitanje na koji način bi u tehničko-metodološkom smislu izveli razdvajanje kandidata i birača po etničkoj osnovi, kako bi osigurali da svaki građanin mora da glasa isključivo za kandidate-pripadnike etničke skupine kojoj i sam pripada, da li bi

\footnotetext{
konstitutivnih naroda i "Ostalih" u institucijama u skladu sa popisom stanovništva iz 1991. godine sve do konačnog provođenja Aneksa 7. Opšteg okvirnog sporazuma za mir u BiH. Aneks 7., kako je poznato, odnosi se na povratak u prijeratna mjesta prebivališta prognanih i izbjeglih lica. Međutim, popis stanovištva iz 2013. godine nedvosmisleno je pokazao da Aneks 7. još uvijek nije proveden! U tom smislu, garancija ustavne naravi u pogledu strukture institucija prema popisu stanovništva iz 1991. godine, uključujući i federalni Dom naroda, predstavlja sredstvo osiguranja zastupljenosti predstavnika manjinskih konstitutivnih naroda iz određenih sredina ili kantona, što nesumnjivo utiče na implementaciju Aneksa 7. u tim sredinama iz razloga koje nije potrebno posebno obrazlagati. Osim toga, riječ je o principu ustavne naravi. Integralnim tumačenjem odredbi prava na snazi, posebno uzimajući u obzir odredbe Aneksa 7. Opšteg okvirnog sporazuma za mir u BiH i Ustava Federacije BiH, kao i nesumnjivi legitimni cilj povratka prognanih i raseljenih lica, navedena odredba Izbornog zakona BiH koja upućuje na posljednji popis trebala bi se tumačiti na način da se upućuje na posljednji relevantan popis stanovništva za ovu vrstu podjele delegatskih mjesta, a to je, imajući u vidu sve navedeno - uključujući i eksplicitne odredbe ustavne naravi, morao biti popis iz 1991. godine. Međutim, Centralna izborna komisija $\mathrm{BiH}$, parcijalno tumačeći odredbe prava na snazi, ne uzimajući u obzir ustavnu obavezu proporcionalne zastupljenosti po popisu iz 1991. godine do potpune provedbe Aneksa 7, kao i sam Aneks 7, utvrdila je raspodjelu delegatskih mjesta za federalni Dom naroda na osnovu popisa iz 2013. godine. Pri tome se nesumnjivo išlo na ruku HDZ-u, ali imajući u vidu konkretna rješenja u smislu formule za popunu Doma naroda, može se konstatovati da je zanemareno realno stanje u pogledu strukture stanovništva u pojedinim kantonima i po popisu iz 2013. godine, što je rezultiralo ogromnim debalansom u pogledu broja delegatskih mjesta koja pripadaju pojedinim konstitutivnim narodima u odnosu na etničku strukturu stanovništva pojedinih kantona.
} 
time, između ostalog, bila narušena tajnost i sloboda glasanja što su principi koji po prirodi stvari čine neizostavni sadržaj demokratskih izbora i sl. Takva metodologija u provođenju izbornog procesa bila je imanentna nekim totalitarnim režimima u prošlosti te, pored toga što je u suprotnosti sa normama, standardima i principima pravne naravi, ne priliči demokratskom društvu niti u najmanjoj mjeri.

\section{Umjesto zaključka}

Na koncu, nameće se potreba da se ukratko ukaže na sadržaj i posljedice principa konstitutivnosti naroda na ustavni poredak BiH. Kao sredstvo koje je bilo nužno za nametanje mirovnih rješenja, zaustavljanje agresije i rata, te uspostavljanje mira i sigurnosti kao najvišeg legitimnog cilja po međunarodnom pravu, princip konstitutivnosti se činio neizbježnim u određenom vremenskom periodu. Čak i nakon stupanja na snagu mirovnih rješenja, u fazi osiguranja kolektivne ravnopravnosti konstitutivnih naroda na svim nivoima vlasti i u oba entiteta - kako je to utvrđeno odlukama Ustavnog suda $\mathrm{BiH} \mathrm{u}$ predmetu U-5/98 koje su kolokvijalno poznate kao „Odluke o konstitutivnosti naroda”, taj princip imao je neku vrstu svrhe i opravdanja. Međutim, budući da je izvan svake razumne sumnje održivi mir i sigurnost, kao najviši legitimni cilj po međunarodnom pravu, uspostavljen - to otpadaju bilo kakvi razlozi za njegovo dalje održavanje na snazi, budući da je riječ o suštinski diskriminatorskom principu. Na to je upozoreno i presudama Evropskog suda za ljudska prava u Strazburu. Rekonstrukciji ustavnog poretka se moralo pristupiti nakon ratifikacije Evropske konvencije i njenih Protokola. Ravnopravnost etničkih skupina, na nivou kolektivnih prava, ne može se u demokratskom društvu postići diskriminacijom i eliminisanjem biračkih prava na individualnom nivou u fazi izbora, odnosno u fazi demokratske legitimacije vlasti čija osnovna premisa je u jednakosti biračkih prava građana. Etnička ravnopravnost se ostvaruje kroz mehanizme i procedure donošenja odluka, a Bosna i Hercegovina je zemlja čiji ustavni sistem - kao niti jedan drugi u demokratskom svijetu, takve vrste mehanizma već posjeduje.

\section{Literatura}

Alan P. Grimes, The Pragmatic Course of Liberalism, The Western Political Quarterly, Vol. 9, 3/1956.;

Allen Buchanan, Political Legitimacy and Democracy, Ethics, Vol. 112, 4/2002.;

Armand A. Maurer, Medieval Philosophy, Second Edition, Pontifical Institute of Mediaeval Studies, Toronto-Ontario, 1982.; 
Adolf Hitler, Mein Kampf, http://der-fuehrer.org/Mein\%20Kampf-Serbisch.pdf (datum pristupa: 30. 8. 2020. godine), e-izdanje;

Aurelije Augustin, De civitate dei, Kršćanska sadašnjost, Zagreb, 1996;

Balázs Fekete, The Unknown Montesquieu An essay on Montesquieu's intellectual background, Iustum Aequum Salutare, 1/2009;

Benito Musolini, Đovani Đentile, Doktrina fašizma, http://www.bosanska-desnica.com/Knjige/Benito_Mussolini_-_Doktrina_fasizma.pdf, (datum pristupa 15. 6. 2011. godine), e-izdanje;

Blandine Kriegel, The Rule of the State and Natural Law, u: Natural Law and Civil Sovereignty: Moral Right and State Authority in Early Modern Political Thought, priredili: Ian Hunter, David Saunders, Palgrave Macmillan, Hampshire-New York, 2002;

Bratoljub Klaić, Rječnik stranik riječi. Nakladni zavod Matice Hrvatske, Zagreb, 2004;

Bruce Ackerman, The New Separation of Powers, Harvard Law Review, Vol. 113, 3/2000;

Carrie Manning, The Making of Democrats, Palgrave Macmillan, 2008;

Daniel Jacobson, Utilitarianism without Consequentialism: The Case of John Stuart Mill, Philosophical Review, Vol. 117, 2/2008;

David Chandler, Bosnia: Faking Democracy After Dayton, Pluto Press, 2000;

David Luscombe, A History of Western Philosophy, Part II: Medieval Thought, Oxford University Press, Oxford-New York, 1997;

Derek Chollet, The Road to the Dayton Accords: A Study of American Statecraft, Palgrave Macmillan, 2005;

Ditrih Ekart, Boljševizam od Mojsija do Lenjina, National Socialist World, 1966;

Donald S. Lutz, Thinking about Constitutionalism at the Start of the Twenty-First Century (Essays in Memory of Daniel J. Elazar), Publius, Vol. 30, 4/2000;

Džon Lok, Dve rasprave o vladi, Utopija, Beograd, 2002.;

Florian Bieber, Post-war Bosnia: Ethnicity, Inequality and Public Sector Governance, Palgrave Macmillan, 2006;

Frederik Kolpston, Istorija filozofije - Srednjovekovna filozofija, Tom II, BIGZ, Beograd, 1989;

Fritz Bennecke, Vom deutschen Volk und seinem Lebensraum, Franz Eher, Munchen, 1937. Jacob Golomb, How to De-Nazify Nietzsche's Philosophical Anthropology? u: Nietzsche, Godfather of Fascism?: On the Uses and Abuses of a Philosophy, priredili: Jacob Golomb, Robert S. Wistrich, Princeton University Press, New Yersey, 2002;

Geoffrey M. Vaughan, Behemoth Teaches Leviathan: Thomas Hobbes on Political Education, Lexington Books, Lanham-Boulder-New York-Oxford, 2002;

George Wright, Religion, Politics and Thomas Hobbes, Springer, Dordrecht, 2006;

Ian Kershaw, Consensus, Coercion and Popular Opinion in the Third Reich: Some Reflections, u: Popular Opinion in Totalitarian Regimes: Fascism, Nazism, Communism, priredio: Paul Corner, Oxford University Press, Oxford-New York, 2009;

Jean Bodin, Šest knjiga o Republici, Politička kultura, Zagreb, 2002;

Jeffrey R. Collins, The Allegiance of, Thomas Hobbes, Oxford University Press Inc., New York, 2005;

Jessica Hawkins, Annotated Bibliography on 'Exploring a 'Social Contract' Approach to the Politics of Poverty Reduction', Chronic Poverty Research Centre, Manchester, 2011;

John A. Simmons, Justification and Legitimacy, Ethics, Vol. 109, 4/1999;

John S. Mill, On Liberty, Yale University Press, New Haven-London, 2003;

Jonathan Riley, Mill on justice, u: Social Justice: From Hume to Walzer, priredili: David Boucher, Paul Kelly, Routledge, Taylor \& Francis e-Library, London-New York, 2005; 
Joseph Canning, A History of Medieval Political Tought 300-1450, Routledge/Taylor \& Francis e-Library, London-New York, 2003;

Joseph Goebbels, Nazi Sozi: Die Fragen und die Antworten fur die National-Sozialisten, Berlin, 1931;

Karl Popper, Otvoreno društvo i njegovi neprijatelji, Tom II, Kruzak, Zagreb, 2003;

Kasim Trnka, Ustavno pravo, Fakultet za javnu upravu, 2006;

Marie Harm, Hermann Wiehle, Lebenskunde fur Mittelschulen, Funfer Teil, Klassed 5 fur Madchen, Halle: Hermann Schrodel Verlag, 1942;

Matthew S.Weinert, Democratic Sovereignty: Authority, Legitimacy, and State in a Globalizing Age, UCL Press/Taylor \& Francis Group, New York, 2007;

Michael P. Zuckert, Natural Rights and the New Republicanism, Princeton University Press, Priceton-New Jersey, 1994;

Milan Sufflay, Izabrani politički spisi, Matica Hrvatska, Zagreb, 2000;

Nicholas Dent, Rousseau, Routledge, London-New York, 2005;

Niko Kolodny, The Explanation of Amour-Propre, Philosophical Review, Vol. 119, 2/2010.; Stefan Grotefeld, Self-Restraint and the Principle of Consent: Some Considerations on the Liberal Conception of Political Legitimacy (Justice in Philosophy and Social Science), Ethical Theory and Moral Practice, Vol. 3, 1/2000;

Omer Ibrahimagić, Državno uređenje Bosne i Hercegovine, Autor, 2005;

Paul McLaughlin, Anarchism and Authority: A Philosophical Introduction to Classical Anarchism, Ashgate Publishing Company, Hampshire-Burlington, 2007;

Petar Stričić, Ugušiti sve glasove osim jednoga, Vjesnik, 14. i 15. maj 2005;

Peter Garnsey, Ideas of Slavery from Aristotle to Augustine, Cambridge University Press, Cambridge-New York-Melbourne, 1999;

Robert Wokler, Rousseau: A Very Short Introduction, Oxford University Press, New York, 2001;

Roger Collins, Early Medieval Europe (300-1000), MacMilllan Education, HoundmillsBasingstoke,-Hampshire-London, 1991;

Stanley G. Payne, A History of Fascism 1914-1945, Routledge/Taylor \& Francis e-Library, 2003;

Stephen J. Finn, Thomas Hobbes and the Politics of Natural Philosophy, Continuum, London-New York, 2006;

Stephen R. C. Hicks, Explaining Postmodernism: Skepticism and Socialism from Rousseau to Foucault, Scholargy Publishing, Tempe-New Berlin-Milwaukee, 2004;

Thomas Wiedemann, Greek and Roman Slavery, Routledge/Taylor \& Francis Group, London-New York, 2005;

Tim Mason, Intention and Explanation: A Current Controversy about the Interpretation of National Socialism, u Nazism, Fascism and the Working Class, priredila: Jane Caplan, Cambridge University Press, Cambridge, 1995;

Zlatan Begić, Opšta načela međunarodnog prava u ustavnom sistemu Bosne i Hercegovine, 5 Anali Pravnog fakulteta u Zenici 9, 2012;

Zvonimir Lauc, Načelo vladavine prava u teoriji i praksi. Pravni vjesnik, 3-4/32, 2016; Miroslav Tuđman, Ivan Bilić, Planovi, sporazumi, izjave o ustavnom ustrojstvu Bosne i Hercegovine 1991. - 1995. Zagreb, 2005;

Žan-Žak Ruso, Društveni ugovor, Filip Višnjić, Beograd, 1993. 


\title{
The Electoral System of Bosnia and Herzegovina: Present Situation and Needed Reforms in the Context of Current Constitutional Solutions
}

\begin{abstract}
Summary
The electoral system of Bosnia and Herzegovina (hereinafter: $\mathrm{BH}$ ) is based on the constitutional and legal solutions which, in their original form, as is well known, do not enable the consistent realization of generally accepted international democratic standards regarding the equality of citizens' suffrage/voting rights. The European Court of Human Rights in Strasbourg has already taken a position on this in certain individual cases. The constant violation and ignoring of the obligations related to the harmonization of the internal legal order of BH with international democratic standards and judgments of the European Court of Human Rights - which are obligations of a constitutional and legal nature - has led not only to further violation of citizens' voting rights, but also to further development of undemocratic political concepts that seek to introduce new forms of discrimination in the phase of elections. The terms and notions are interpreted and explained in a hitherto unknown and fundamentally wrong way in the theory and practice of constitutional and public law - such as "legitimate representation of constituent peoples", "authentic representatives of constituent peoples", which is followed by the efforts to "nationalize" constituent peoples etc. and with the intention of any theoretical grounding of these inconsistent political views. Besides, in the conditions of undemocratic constitutional solutions and taking into account the real power of decision-making within institutions, the election winner is not crucially determined by the citizens in the elections - as shown by the last general elections in 2018. Among the other things, the absolute election winner regarding possibility of establishment of government and blocking the implementation of election results was promoted by the decision/Instruction of the BH Central Election Commission related to the distribution of delegate seats in the House of Peoples of the Federation of $\mathrm{BH}$, and thus (almost in advance!) determined by inconsistent constitutional/legal solutions and electoral geometry. This further disqualifies the position of the citizens and violate the generally accepted international democratic standards without which a democratic society cannot exist and develop. All of this seriously violate the democratic legitimacy and capacity of the institutions as well as the principle of rule of law and fulfillment of legal and political obligations on the path of European integrations. In contrast, BH's legal obligations towards electoral reform, no matter how many different modalities they may have, are quite clear and imply, in the first place, equality of active and passive voting rights of citizens regardless of ethnicity or any other circumstance, which is subject of consideration on this occasion.
\end{abstract}

Key words: BH Constitution, constituency of peoples, equality of citizens, democratic standards, suffrage/voting rights, reform. 